\title{
Understanding Marine Mussel Adhesion
}

\author{
Heather G. Silverman, Francisco F. Roberto \\ Biological Systems Department, Idaho National Laboratory, Idaho Falls, Idaho 83415, USA \\ Received: 7 March 2007 / Accepted: 5 September 2007 / Published online: 8 November 2007
}

\begin{abstract}
In addition to identifying the proteins that have a role in underwater adhesion by marine mussels, research efforts have focused on identifying the genes responsible for the adhesive proteins, environmental factors that may influence protein production, and strategies for producing natural adhesives similar to the native mussel adhesive proteins. The production-scale availability of recombinant mussel adhesive proteins will enable researchers to formulate adhesives that are waterimpervious and ecologically safe and can bind materials ranging from glass, plastics, metals, and wood to materials, such as bone or teeth, biological organisms, and other chemicals or molecules. Unfortunately, as of yet scientists have been unable to duplicate the processes that marine mussels use to create adhesive structures. This study provides a background on adhesive proteins identified in the blue mussel, Mytilus edulis, and introduces our research interests and discusses the future for continued research related to mussel adhesion.
\end{abstract}

Keywords: adhesion - biomimetics marine mussel (Mytilus edulis) -

recombinant protein

\section{Introduction to Biological Adhesion}

Biomimetics. Biomimetic materials are designed to mimic compounds with a biological origin. The biomaterial development field is actively pursuing the use of various synthetic and natural proteinand carbohydrate-containing compounds. The production of ecologically friendly materials also is of importance as a result of a rapid increase in the world's population and the subsequent en-

Correspondence to: Heather G. Siverman; E-mail: Heather.Silverman @inl.gov vironmental problems associated with product wastes (Arora and Arora 2004). The key interest in biomimetic adhesives is the interaction between the material and a surface, whether that surface is of biological or nonbiological origin. Scientific studies in the interdisciplinary field of biomaterial research include areas such as surface characterization, protein adsorption, and adhesion behavior (Kirkpatrick et al. 1997). Table 1 briefly describes biomolecules with adhesive properties used for biomimetic research. Many of the proteins are scleroproteins, which contribute mechanical strength to supporting structures in animals. Waite (1983a, b) has commented on the durability of these proteins, in terms of relative insolubility, resistance to proteolytic hydrolysis, or other chemical dissolution. Repetitive amino acid motifs and intermolecular and intramolecular cross-linking are common; DOPA-containing scleroproteins produced through posttranslational modification of tyrosine by various organisms leads to further stabilization or curing of scleroproteins involved in adhesion and/or protection of more flexible structural proteins.

The production of an underwater adhesive that mimics the properties of marine mussels is a challenge that has received considerable attention. Many of the mussel adhesive proteins identified to date are polyphenolic proteins. Polyphenolic proteins are nontoxic, biodegradable, and have low immunogenic qualities that make them highly attractive for environmental, medical, and industrial purposes.

Biological Adhesion. Naturally produced adhesives are common in many biological systems and are known for their superior strength and durability compared with man-made materials. Examples of specialized biological systems that generate a vast amount of adhesives research include bacteria, spiders, marine tubeworms, sea cucumbers, barnacles, and mussels. Many bacteria synthesize exopolysaccharides-extracellular protective adhesive matrixes. 
Table 1. Research targets for biomaterial development

\begin{tabular}{|c|c|}
\hline Biological Target & Description \\
\hline Keratin & $\begin{array}{l}\text { A hard, durable insoluble, structural protein that is the primary component of horns, } \\
\text { hoofs, feathers, skin, hair, and nails; a scleroprotein }\end{array}$ \\
\hline Elastin & $\begin{array}{l}\text { An insoluble protein found in connective tissue and known for its elasticity and } \\
\text { similarity to collagen; a scleroprotein }\end{array}$ \\
\hline Collagen & 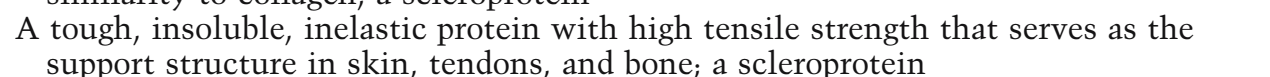 \\
\hline Silks & $\begin{array}{l}\text { High tensile strength protein fibers that contain various proteins (fibroin, spidroin); } \\
\text { most commonly from spiders and silkworms }\end{array}$ \\
\hline $\begin{array}{l}\text { Fibrin (and other coagulation } \\
\text { system proteins) }\end{array}$ & $\begin{array}{l}\text { A sticky, insoluble, clot-forming protein formed by constituents in the blood; } \\
\text { a scleroprotein }\end{array}$ \\
\hline Chitin & $\begin{array}{l}\text { A specialized carbohydrate containing nitrogen (nitrogenous polysaccharide); found } \\
\text { in the cell walls of certain fungi and in the exoskeletons of arthropods }\end{array}$ \\
\hline Cellulose & $\begin{array}{l}\text { An insoluble complex carbohydrate (polysaccharide composed of linked glucose units) } \\
\text { main constituent of the cell walls of plants }\end{array}$ \\
\hline Mucin & $\begin{array}{l}\text { A nitrogenous, conjugated protein (protein linked to a sugar) found in mucous } \\
\text { secretions; acts as a lubricant and protects body surfaces }\end{array}$ \\
\hline
\end{tabular}

Bacteria can form layers, or biofilms, on a variety of surfaces by embedding cells in exopolysaccharides. The polysaccharide-based holdfast of the aquatic bacterium Caulobacter crescentus has been shown recently to demonstrate the strongest adhesive force measured in bacteria (Tsang et al. 2006). Spiders also express adhesive proteins by synthesizing different types of silk, all of which have high tensile strength, extensibility, and an energy-dissipative viscoelastic response that is not matched by synthetic polymers (Zhou et al. 2001; Vollrath 2000). Current research with spider silks involves the production of spider silk in other organisms, a technique known as recombinant protein expression (Piruzian et al. 2003).

Many marine organisms have developed adhesive strategies to deal with the dynamic ocean environment, particularly at the tidal interface. Marine invertebrates attach permanently or temporarily to inanimate, and sometimes living, surfaces. Therefore, adhesive mechanisms have evolved to promote attachment. The marine polychaete Phragmatopoma californica is a tubeworm that builds protective "tubes" with secreted proteinaceous cement mixed with shells and sand particles from the sea floor. The cement adheres rapidly to a variety of materials in seawater (Stewart et al. 2004; Zhao et al. 2005). The sea cucumber (Holothuria forskali) reacts defensively through the discharge of Cuvierian tubules that ensnare their threat. Biochemical analysis of the tubules indicates a 3:2 protein to carbohydrate ratio, with a high proportion of highly insoluble protein. The soluble protein component appears to contain up to ten glycine and acidic amino acid-rich proteins ranging in size from 17 to 220 kilodaltons (DeMoor et al. 2003).
Barnacles adhere directly and permanently to surfaces, such as underwater substrata (ship hulls, oil platforms, and pipelines). Initial attachment of barnacle cyprid larvae is via o-quinone cross-linking that resembles the dihydroxyphenylalanine (DOPA)containing adhesive proteins of Mytilus spp. (Wiegemann 2005), but the adult barnacle cement is substantially different-comprised of three groups of proteins that contain high levels of the amino acids serine, threonine, glycine, and alanine (Kamino et al. 2000; Wiegemann 2005). A pattern of short, alternating regions of hydrophobic and hydrophilic residues throughout the largest of the three groups of proteins has been noted and suggested that these alternating motifs may have a role in assembly in seawater (Kamino et al. 2000). Marine and freshwater mussel adhesive proteins differ from barnacle cement proteins because of the presence of repetitive amino acid motifs (characterized by a high polyphenolic content), high levels of the modified amino acid 3,4-DOPA, and chemical modifications (hydroxylations) to specific amino acids (Burzio et al. 1997). At least ten different adhesive-related proteins from the marine mussel $M$. edulis have been identified, reflecting the greater ease of working with the adhesive structures of this organism and also its popularity as a target for biomimetic research.

Marine mussels, such as the blue mussel, $M$. edulis, attach to a variety of surfaces in an aqueous environment by using a natural adhesive that is incredibly strong and durable. There are no synthetic glues that can be similarly applied in an aqueous environment and are impervious to water and turbulent forces. Previous research has shown that one of the proteins in the adhesive, Mytilus edulis foot protein 1 (Mefp-1), bonds to glass, plastic, 
wood, concrete, and Teflon ${ }^{\circledR}$. Nine other adhesiverelated proteins from $M$. edulis have been identified to date. A tenth is implicated but has not been isolated. The precise mechanism for assembly of the ten proteins-Mefp-1, -2, -3, -4, -5; collagens such as precollagen-D, -P (variant $\mathrm{P} 22$ and $\mathrm{P} 33$ ), and -NG; proximal matrix thread protein (PMTP-1 and -1a); and a polyphenol oxidase-is not understood. There also may be additional proteins involved in the formation of the adhesive. Figure 1 illustrates adhesion of $M$. edulis to seaweed, other mussels, and a stainless steel surface.

Adhesion Mechanisms in Mussels. The mollusk byssus evolved to anchor postlarval organisms during metamorphosis. Some species of mussels have retained the byssus in the adult animal, permitting a transition from a bottom-dwelling existence to an epibenthic lifestyle. Within the Mytilidae, examples of mussels across this range of marine lifestyles can be observed, from the burrowing Geukensia demissa, to Mytilus edulis and Bathymodiolus childressi, which live entirely exposed attached to hard surfaces, and intermediate species, such as Modiulus modiolus, which can survive under mixed conditions (Brazee and Carrington 2006). Common features of the byssus in the Mytilidae include a root attached to the byssal retractor muscle, a stem extending from the root, and individual byssal threads which are attached to overlapping cuffs of the root.

The strength of mussel adhesive scleroproteins is attributed to the introduction of cross-links between polymer chains of individual adhesive proteins (a process called "curing"). Curing, or hardening, of the polyphenolic mussel proteins is believed to require a catecholic precursor (e.g., DOPA) and the presence of a catechol oxidase (Waite 1990).

Individual adhesive proteins from mussels are produced by the foot organ of the animal. The proteins are stockpiled in the foot then secreted or released into the byssal groove, which creates a template for thread and plaque formation to form strong attachments underwater. The reactive, oxidized form of DOPA, quinone, is thought to provide the moisture-resistance characteristic of mussel underwater adhesion ( $\mathrm{Yu}$ and Deming 1998; Yu et al. 1999). DOPA is formed from the hydroxylation of tyrosine residues by a polyphenoloxidase (tyrosinase). DOPA can complex with metal ions and oxides $\left(\mathrm{Fe}^{3+}, \mathrm{Mn}^{3+}\right)$ and semimetals, such as silicon, thus explaining its ability to adhere to rocks and glass (Sever et al. 2004). Sun and Waite (2005) have reported an incremental posttranslational modification of tyrosine to DOPA from the proximal end to distal tips of threads, coupled with a selective localization of metals (aluminum, calcium, iron,

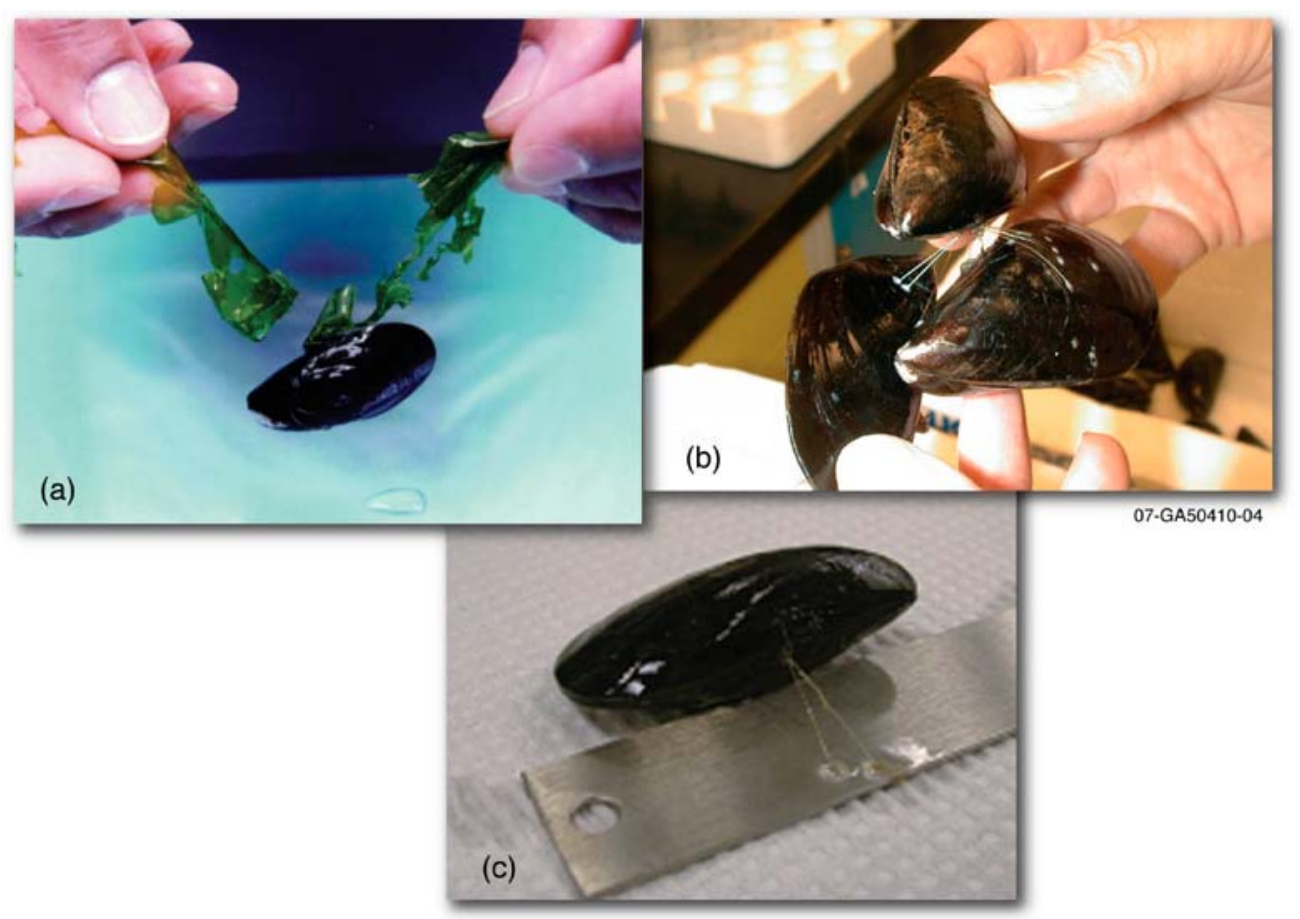

Figure 1. M. edulis attachment to $(\mathbf{a})$ seaweed, $(\mathbf{b})$ other mussels, and $(\mathbf{c})$ a stainless steel surface. 
and silicon) and an associated iron gradient. The sequestering of iron occurs during feeding rather than after threads have been formed. Thus, iron is incorporated in a chemical gradient pattern similar to that of DOPA during secretion of byssal threads and plaques. The identification of 12 variants of the DOPA-rich adhesive foot protein 3 from Mytilus californianus (Mcfp-3) further supports the intricate role of DOPA in marine mussel adhesion (Zhao et al. 2006).

The catecholic content of mussel adhesive proteins has been linked to hydrogen-bonding and metal-liganding (strong chelating) capabilities (Monahan and Wilker 2003; Deming 1999). Examples of proteins undergoing the $O$-quinone intermediate process (quinone tanning) include collagen (mussel byssal threads), cellulose, chitin, and mineral deposits (mussel shells). Figure 2 illustrates the chemical steps for hydroxylation of tyrosine and DOPA residues in $M$. edulis polyphenolic proteins.

Other constituents of mussel adhesive proteins include lysine and glycine. Lysine may contribute to adhesion via ionic bonding to negatively charged surfaces, such as collagen and acidic polysaccharides (Suci and Geesey 2000; Olivieri et al. 2002), and intermolecular cross-linking with $o$-quinones. Glycine may contribute to adhesion through the open, extended conformation it imparts on protein structures. Histidine, an amino acid exhibiting a gradient pattern and present in high concentrations in the distal region of byssal threads, has been correlated to transition metal content (zinc or copper) and adhesion in marine mussels (Waite et al. 2004). The exceptional strength of mussel adhesive proteins is undoubtedly the result of the repetitive nature of many of the individual proteins (decapeptide and hexapeptide repeats in Mefp-1 and

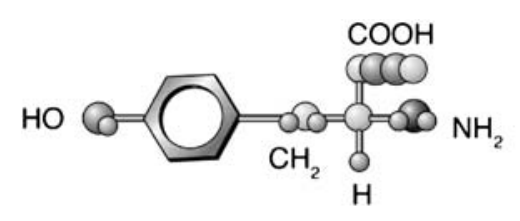

tyrosine

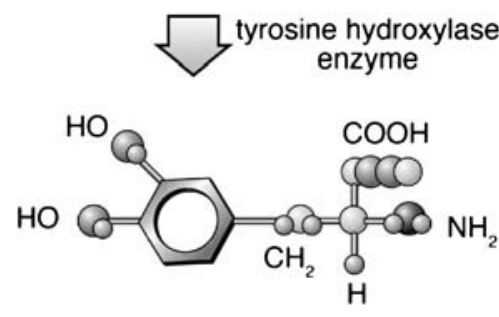

dihydroxyphenyalanine (DOPA)

07-GA50410-01

Figure 2. Hydroxylation of tyrosine residues in $M$. edulis polyphenolic proteins. hydroxyproline repeats in collagens), the modification of individual amino acids (e.g., hydroxylation of proline and tyrosine), and the gradient nature of byssal attachment devices.

This gradient nature was first noted by Brown in 1952 (referenced by Brazee and Carrington 2006), who observed corrugated proximal (to the organism) and smooth distal regions. The development of our understanding of the transition of mechanical properties along the thread length, from the more flexible proximal region close to the soft tissues of the mussel, through the collagenous main body of the thread, to the stiffer, less extensible distal region, and the exquisite fine tuning of protein components to impart these properties, has been concisely reviewed recently (Brazee and Carrington 2006). Total mussel adhesive strength is a function of the individual adhesive proteins secreted by the animal, their association with other proteins, their distribution along the thread, and their proximity to materials of differing moduli. Details of the individual adhesive protein components are described in the next section.

\section{Components of Mussel Adhesion}

Attachment in Mussels: The Byssus. The byssus, an exogenous attachment structure, was first described in 1711 (Brown 1952). High concentrations of polyphenolic proteins (e.g., DOPA), the presence of collagen, and the presence of a catechol oxidase were among the first biochemical observations of byssal attachments. Environmental factors, such as salinity, temperature, $\mathrm{pH}$, season, and substratum choice, as well as biological factors, such as age and metabolic state of the animal, affect the efficiency and strength of byssal attachment to surfaces (Van Winkle 1970; Crisp et al. 1985; Carrington 2002).

The stem is rooted in the byssal retractor muscles at the base of the foot organ. The byssal threads, flexible structures of variable dimensions ( $\sim 0.1 \mathrm{~mm}$ diameter, $2-4 \mathrm{~cm}$ length) and strength, originate from the stem. A byssal thread consists of a flexible, collagenous inner core surrounded by a hardened, cured polyphenolic protein. Numerous researchers photographed the collagen core in the 1930s (Brown 1952), well before three unique collagenous proteins were identified and characterized by Qin and Waite $(1998,1995)$. The outer polyphenolic protein, believed to undergo a quinone tanning-type reaction with a specialized catechol oxidase enzyme, is Mefp-1. Designation of this byssal thread polyphenolic adhesive protein, as well as subsequent adhesive proteins identified in Mytilus edulis, is preceded by the genus and species. The 
byssal structure culminates in a polyphasic plaque of varying size, dependent on both the size of the animal and the age of the byssus (Crisp et al. 1985). Plaques are commonly only $\sim 0.15 \mathrm{~mm}$ in diameter where they meet the thread and $\sim 2-$ to $3-\mathrm{mm}$ diameter at the substrate interface. Plaque formation occurs from the deposition of proteins that originate in the foot organ. To date, five specialized adhesive proteins have been identified in byssal plaques from $M$. edulis: Mefp-1, -2, -3, -4, and -5. Figure 3 illustrates the anatomy of $M$. edulis and the associated byssus structures. Figure 4 illustrates the location of the adhesive-related proteins identified in the byssus of M. edulis.

Mechanical Properties of Mussels. The most extensive research about the adhesive mechanical properties of mussels has been with $M$. edulis. The breaking energy of intact byssal threads is reported to be $12.5 \times 10^{6} \mathrm{Jm}^{-3}$ versus tendon $\left(2 \times 10^{6} \mathrm{Jm}^{-3}\right.$ to $\left.5 \times 10^{6} \mathrm{Jm}^{-3}\right)$ and silk $\left(50 \times 10^{6} \mathrm{Jm}^{-3}\right.$ to $\left.180 \times 10^{6} \mathrm{Jm}^{-3}\right)$ (Denny 1988). Bond strengths are between 0.1 to $10 \times 10^{6} \mathrm{Nm}^{-2}$, depending on the surface for adhesion (Waite 1999). Byssal thread strength at the distal portion of threads is as strong as a vertebrate tendon but three to five times more extensible (Qin and Waite 1998). Byssal thread strength at the proximal portion of threads is weaker but 15 to 20 times more extensible. Strain energy density of threads approaches that of silk, approximately six times tougher than a tendon (Smeathers and Vincent 1979; Coyne et al. 1997). Byssal threads can recover initial length and

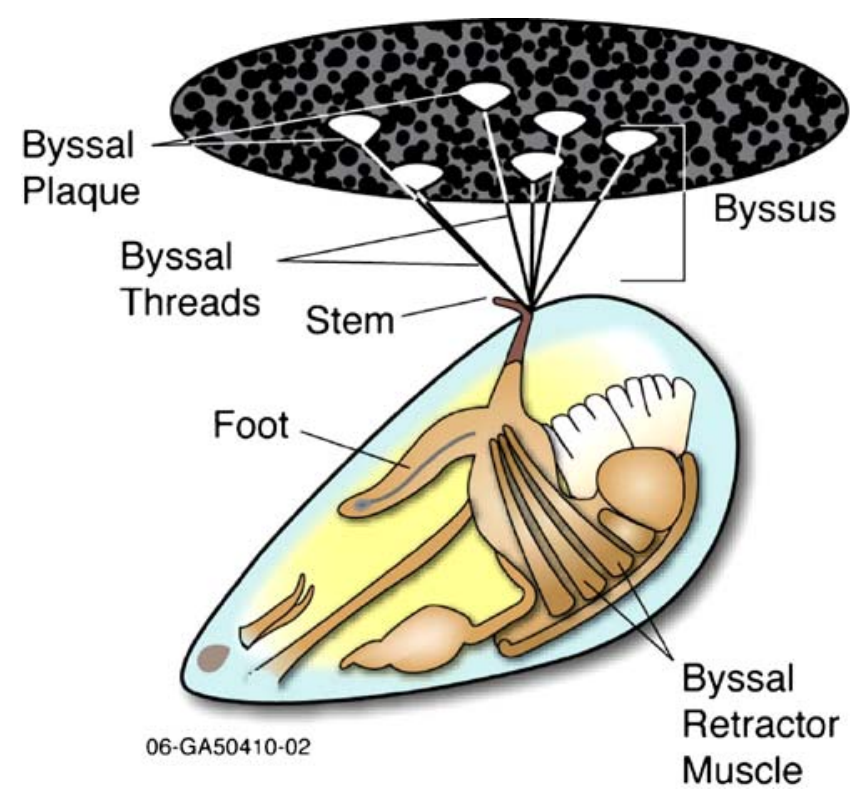

Figure 3. Anatomy of M. edulis mussel and byssus structures. stiffness if given sufficient relaxation time (Bell and Gosline 1996).

Mefp-1, the most studied mussel adhesive protein, has adhesive properties comparable to synthetic cyanoacrylate and epoxy resins. These resin adhesives are popular because of their high bond strengths, quick polymerization, and ability to bond to a number of substrates (metals, glass, ceramic) (Savla 1977; Coover and McIntire 1977). Research related to the mechanical properties of individual $M$. edulis adhesive proteins is limited because of the difficulty in obtaining large quantities of isolated proteins for adhesive testing.

\section{Byssal Thread Proteins}

Byssal Thread Polyphenolic Protein: Mefp-1. Mefp-1 was the first polyphenolic protein to be identified in the mussel byssus (Waite and Tanzer 1981; Waite 1983b). The primary location of Mefp-1 is in the byssal threads, cross-linked via a polyphenol oxidase to form a hardened sheath around the flexible, collagenous inner core. Byssal plaques contain $\sim 5 \%$ of Mefp-1 as well. Mefp-1 is a large (897 amino acids), basic hydrophilic protein with very little secondary structure and a molecular mass of $115 \mathrm{kDa}$, based on mass spectroscopy (Filpula et al. 1990). Decapeptide and hexapeptide repeats containing numerous posttranslational modifications $(\sim 60-70 \%$ of the amino acid residues are hydroxylated) provided the first indication of an adhesive-related protein unlike any others identified in nature. The hexapeptide repeat is made up of the amino acids AKPTYK. The major decapeptide consensus repeat, consisting of the amino acids AKPSYP'P' 'TYK (in which $\mathrm{P}$ represents proline, Y represents DOPA, P' represents trans-2,3cis-3,4-dihydroxyproline, and $\mathrm{P}$ " represents trans-4hydroxy-L-proline) occurs $\sim 80$ times in Mefp- 1 . DOPA residues constitute $10-15 \%$ of the protein (Waite 1983b). The open conformation of the protein is believed to allow functional groups full accessibility for cross-linking interactions with other proteins and a variety of surfaces, including glass, Teflon ${ }^{\circledR}$, and metals. Mepf-1 has been characterized as possessing random coil conformations with helix-like decapeptide segments under physiologic conditions (Haemers et al. 2005). Our laboratory recently has deduced complementary DNA (cDNA) sequences for Mefp-1 (GenBank Accession number: AY845258 and AY845259).

Other Mytilus mussel species contain a protein analogous to Mefp-1, with differences in the decapeptide repeat frequency, residue composition, and nonrepetitive regions; these species include $M$. galloprovincialis (Mgfp-1) (Inoue and Odo 1994); 


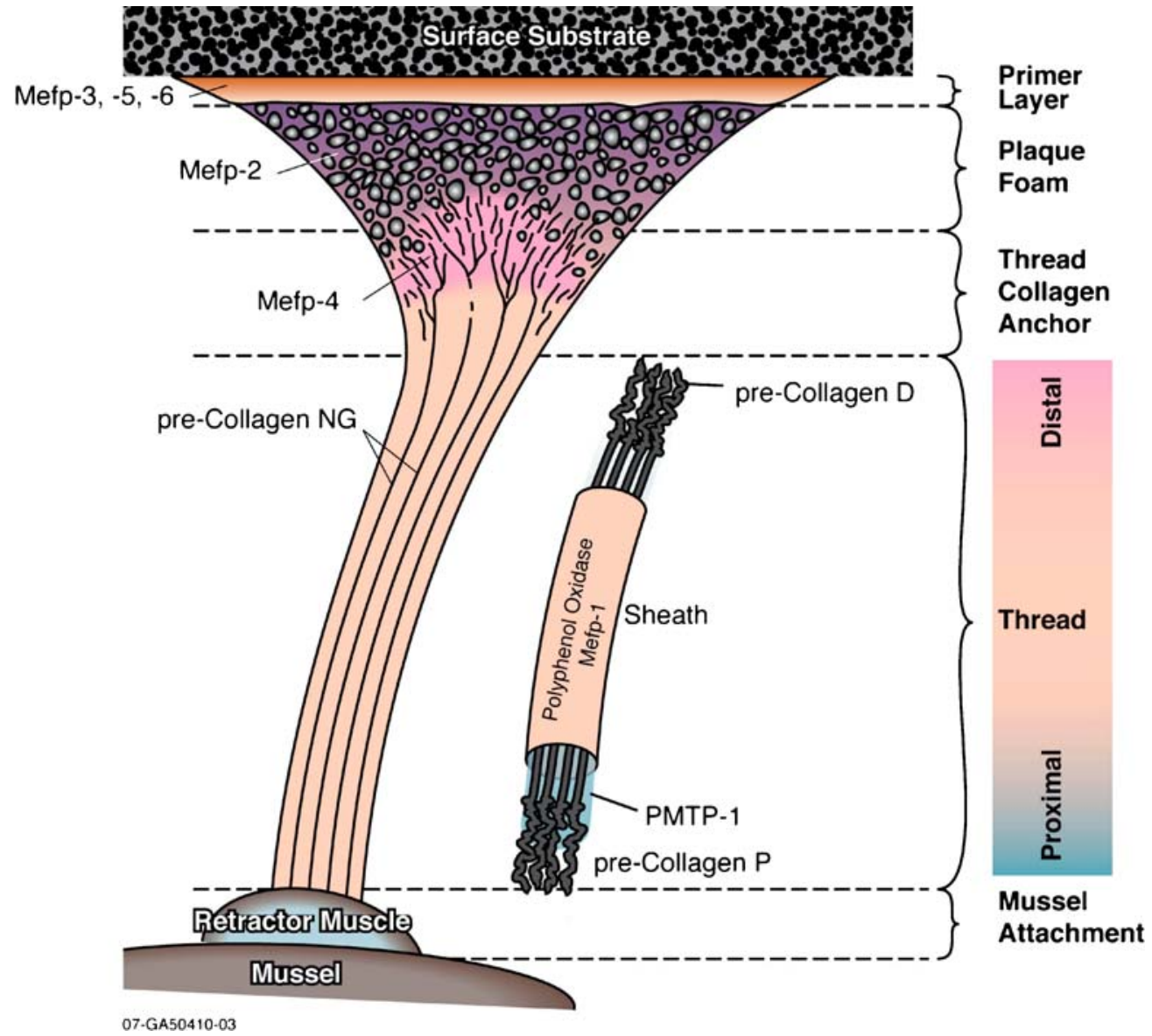

Figure 4. Location of adhesive-related proteins identified in the byssus of $M$. edulis.

M. coruscus (Mcfp-1) (Inoue et al. 1996b); $M$. trossulus (Inoue et al. 1995b); M. californianus Conrad, California mussel (Waite 1986); M. chilensis (Pardo et al. 1990); and M. sp. JHX-2002 (Wang et al. 2004).

Mefp-1-like adhesive proteins from mussels outside of the Mytilus genus also have been identified: Dreissena polymorpha, zebra mussel (Dpfp-1) (Rzepecki and Waite 1993; Anderson and Waite 2000); Dreissena bugensis, quagga mussel (Dbfp-1) (Anderson and Waite 2002); Perna viridis, green mussel (Pvfp-1) (Ohkawa et al. 2004); Perna canaliculus, green shell mussel (Pcfp-1) (Zhao and Waite 2005); Guekensia demissa, ribbed mussel (Waite et al. 1989); Limnoperna fortunei, Asian freshwater mussel (Lffp-1) (Ohkawa et al. 1999); Aulacomya ater (Saez et al. 1991); and Choromytilus chorus (Pardo et al. 1990). Polyphenolic proteins from other marine mussels also have been compared with Mefp-1 (Rzepecki et al. 1991).

Mefp-1 requires oxidization of tyrosine residues by catechol oxidase, tyrosinase, or sodium periodate for conversion to the reactive DOPA residues required for strong adhesion. The enzyme catalyzing oxidation may serve as an oxidative agent and as a copolymer. Molecular oxygen can be used to further oxidize DOPA to a quinone. Possible cross-linking agents are oxygen, polyvalent metal ions $\left(\mathrm{Fe}^{3+}\right.$ and $\mathrm{Al}^{3+}$, aldehydes, and many types of bi/polyfunctional cross-linkers. The hydroxylation of DOPA from incubation with tyrosinase has been shown to form 3-, 4-, 5-trihydroxyphenylalanine (TOPA), in a decapeptide related to Mefp-1 (Burzio and Waite 2002). The prospective functions of TOPA isomers have included metal binding, wound healing, and adhesion.

Mefp-1 has been previously commercialized as a source for mussel adhesive protein. Companies supplying Mefp-1 have obtained adhesive protein from the byssal structures by using protein extraction techniques (Sigma-Aldrich: "Adhesive Protein"; Swedish BioScience Laboratory: "MAP"; BD Biosiences Clontech: Cell-Tak ${ }^{\mathrm{TM}}$ ) and recombinant protein techniques using synthetic gene constructs (Genex Corp.: "AdheraCell”). However, currently there are no commercial sources for pure Mefp-1 because of the high cost of extraction methods and inconsistencies in quality of protein 
from recombinant protein techniques /Cell-Tak ${ }^{\mathrm{TM}}$ Cell and Tissue Adhesive is a formulation of multiple polyphenolic proteins from Mytilus edulis). The laboratory-prepared products have not demonstrated comparable strength to the natural protein. Our laboratory is currently conducting research on the large-scale production of recombinant Mefp-1 protein (Silverman and Roberto 2006a).

Byssal Thread Polyphenol Oxidase. The Enzyme Commission of the International Union of Biochemistry classifies each enzyme into six major groups according to the reactions catalyzed. Enzymes are given specific nomenclature, with the letters "EC" prefacing the specific subclass with its major grouping (http://www.chem.qmul.ac.uk/iubmb/enzyme/). Polyphenol oxidases fall under the broad enzyme grouping of "oxidoreductase." They are oxygen transferring, copper metalloproteins having both catecholase (act on diphenols) and cresolase (act on monophenols) activity. Polyphenol oxidases catalyze the orthohydroxylation of phenols to catechols and the dehydrogenation of catechols to orthoquinones. A monophenol monooxygenase (EC 1.14.18.1), more traditionally called tyrosinase, can oxidize tyrosine to L-DOPA and L-DOPA to o-quinone (Worthington 1993). A catechol oxidase (EC 1.10.3.1) can oxidize LDOPA to $O$-quinone. The enzymatic formation of $O$ quinone is a browning/tanning/curing reaction that occurs in plants, bacteria, and animals (Waite 1990). The adhesive properties of marine mussels have been demonstrated by metal complex formation of DOPA and the intermolecular cross-linking of o-quinone with lysine residues.

Very little definitive information exists about the polyphenol oxidase(s) present in $M$. edulis that is responsible for tyrosine and DOPA conversions in byssus formation. A cytochemical study of the enzyme gland in the foot organ of $M$. edulis demonstrated phenol oxidase activity in the Golgi complex but not the secretory granules (Zuccarello 1981). Waite (1985) measured catechol oxidase activity from enzyme gland extractions and whole byssus structures. The native enzyme was shown to prefer diphenols over monophenols as substrates. A single, purified protein was not obtained, and the enzyme was estimated to have subunits and a molecular weight of $120 \mathrm{kDa}$. Burzio (1996) extracted two catechol oxidases from $M$. edulis byssal threads, plaques, and feet. Both the byssal catechol oxidase-high molecular weight (BCO-H, $174 \mathrm{kDa}$ ) and byssal catechol oxidase-low molecular weight (BCO-L, $60 \mathrm{kDa}$ ) isozymes only oxidized catechols to $O$-quinones, and their amino acid composition was similar to other catechol oxidases found in nature. Again, homogenous purification was not possible. Recently, Hellio et al. (2000) purified a $34 \mathrm{kDa}$ phenol oxidase monomer from mussel feet. The substrate specificity of the enzyme was greatest toward dihydroxyphenols (L-DOPA and catechol), followed by trihydroxyphenols, suggesting that there may be at least two forms of phenol oxidase involved in mussel adhesion. Extremely low relative activity was observed with monohydroxyphenols. Thus, the specific identification of the polyphenol oxidase enzyme(s) involved in byssus formation continues to elude researchers.

Various compounds have been found to inhibit the activity of the $M$. edulis phenol oxidases identified above: oxygen competitors /cyanide and nitrogen), metal chelators (diethyldithiocarbamate (DETC) and ethylenediaminetetraacetic acid (EDTA)), a reducing agent (L-ascorbic acid), and the competitive inhibitors benzoic acid and L-DOPA, with respect to 4-methylcatechol and L-DOPA (Waite 1985; Burzio 1996; Hellio et al. 2000). There is currently extensive research in the area of antifouling methods to prevent attachment of marine and/or freshwater mussels to surfaces. These studies rely on understanding the biochemical properties of mussel adhesive proteins, including polyphenol oxidase, and the surface chemistry of paints, varnishes, and other materials.

\section{Byssal Thread Collagens}

All collagens in nature contain a triple-helical domain with the sequence repeat $(\mathrm{Gly}-\mathrm{X}-\mathrm{Y})_{\mathrm{n}}$, in which Gly is glycine, $\mathrm{X}$ often is proline, and $\mathrm{Y}$ is usually hydroxyproline. This triple-helical configuration provides mechanical strength but on its own offers little flexibility and elasticity. The collagens present in $M$. edulis byssal threads contain additional sequence domains that make the byssal thread approximately six times tougher than the human Achilles tendon (Smeathers and Vincent 1979; Coyne et al. 1997). Two M. edulis collagens appear in a gradient fashion in byssal threads, and a third is distributed evenly throughout the thread. Analogous byssal collagens have been identified in M. galloprovincialis (Lucas et al. 2002; Hassenkam et al. 2004).

Proximal Collagen (Col-P). The proximal region of a byssal thread (the region closest to the animal) consists of a unique, natural co-polymer, termed proximal collagen (Col-P) (Coyne et al. 1997; Qin and Waite 1995). This protein is an incredible shock absorber with 160\% extensibility. The precursor collagen (PreCol-P) has a molecular mass of $95 \mathrm{kDa}$ 
and consists of seven domains: representative amino and carboxyl termini; a large, central collagenous domain $(40 \mathrm{kDa})$ flanked by elastinlike domains (11 kDa each); and small, histidinerich domains $(5 \mathrm{kDa})$ that flank the elastin-like domains. A small acidic patch is present between the collagen and elastin-like domains at the carboxy end of the protein. The collagen domain, coupled with the presence of the two, elastin-like domains, provides for an incredibly tough and extensible proximal region in byssal threads. Histidine-rich domains are believed to function in metal binding. The transition metal zinc has been detected in $M$. edulis byssi, supporting theories of $\mathrm{Zn}^{2+}$-mediated cross-linking in the terminal domains of Col-P. Two variants of PreCol-P have been implicated in molecular dovetailing between the proximal byssal thread and the byssal stem (P22 and P33) (Coyne and Waite 2000). The presence of these variants suggests a mechanism in which mussels can mitigate stresses by overlapping different proteins, a phenomenon that occurs between tendon and bone (Fukuta et al. 1998) and in spiders from frame silk (web frame and radial supports) to viscid (gluecovered) silks (Guerette et al. 1996).

Distal Collagen (Col-D). The distal region of a byssal thread contains another natural co-polymer: distal collagen (Col-D). The Col-D is stiffer than the Col-P. The precursor collagen (PreCol-D) (molecular mass $97 \mathrm{kDa}$ ) also contains seven separate domains: representative amino and carboxyl termini; a central, collagenous domain larger than PreCol-P (45.5 kDa); silk fibroin-like domains flanking the collagen domain (5 and $15 \mathrm{kDa})$; and small, histidine-rich domains (7 and $5 \mathrm{kDa}$ ) that flank the silk-fibroin domains. A large collagen domain (175 repeats of Gly-X-Y), a small, acidic patch, and the histidine-rich domains are similar to the PreCol-P structure. The presence of silk-fibroin domains allow for extensibility in PreCol$\mathrm{D}$, as is the case for elastin in PreCol-P. However, the distal region of byssal threads is localized in straight bundles (strong and stiff), whereas the collagen fibers are coiled in the proximal region (pliable and elastic) (Waite et al. 1998). Before the characterization of PreCol-D, silk fibroin domains had been previously reported only in arthropods.

Pepsin-resistant Nongradient Collagen (Col$N G)$. The entire length of a byssal thread contains a third block copolymer-like protein, pepsinresistant nongradient collagen (Col-NG) (Qin and Waite 1998). The precursor pepsin-resistant nongradient collagen (PreCol-NG) (molecular mass $76 \mathrm{kDa}$ ) is believed to function as a mediator between PreCol-D and PreCol-P. It consists of a central collagenous domain $(\sim 38 \mathrm{kDa})$, an acidic patch, and histidine-rich termini, similar to PreCol$\mathrm{D}$ and PreCol-P. The regions flanking the collagen domain contain $\left(\mathrm{X}-\mathrm{Gly} \mathrm{y}_{\mathrm{m}}\right.$ repeats (which are similar motifs found in plant cell walls) in addition to the familiar silk fibroin-like domains that are present in PreCol-D. There is a larger distribution of tyrosine in the histidine domain of the $\mathrm{N}$ - and $\mathrm{C}$ terminal sequences of PreCol-NG compared to the other two collagens.

The elastic domains of PreCol-P, the silk fibroin-like domains of PreCol-D, and the plant cell wall-like domains of PreCol-NG characterize the unique, collagenous block copolymers found in the byssal threads of $M$. edulis.

Proximal Thread Matrix Protein (PTMP). The proximal portion of each byssal thread contains a water-soluble, noncollagenous protein designated proximal thread matrix protein (PTMP; Sun et al. 2002). This $\sim 50 \mathrm{kDa}$ matrix protein has a capacity for collagen binding and resembles the von Willebrand factor in amino acid sequence, antigenicity, and its stiffening effect. Two variants have been identified in $M$. edulis (PTMP1a and PTMP1b). A similar PTMP1-like cDNA has been found in M. galloprovincialis.

\section{Byssal Plaque Polyphenolic Proteins}

Mefp-2. Mefp-2 is found exclusively in byssal plaques, constituting from $25 \%$ to $40 \%$ of the total plaque proteins. Unlike Mefp-1, Mefp-2 is a smaller adhesive protein (molecular mass $42-47 \mathrm{kDa}$ ) with only 2 to $3 \mathrm{~mol} \%$ DOPA and no hydroxylation of proline to trans-2,3-cis-3,4-dihydroxyproline or trans4-hydroxy-L-proline. The DOPA residues occur primarily in the $\mathrm{N}$ - and $\mathrm{C}$ - terminal regions of the protein. Mefp-2 contains considerable secondary structure and is relatively resistant to a variety of proteases (compared with Mefp-1), an important characteristic for integrity of the byssal plaque. The high cysteine content $(6-7 \mathrm{~mol} \%)$, coupled with tandem, repetitive motifs similar to epidermal growth factor, suggests that Mefp- 2 is an adhesive protein with a stabilization role in the byssus (Inoue et al. 1995a). A Mefp-2 multigene family may exist, based on evidence that at least three different repetitive motifs have been identified in the primary protein sequence (Rzepecki et al. 1992). A published full-length gene sequence for Mefp-2 is not available. However, an investigation of Mefp-2 cDNA sequences identified by our laboratory supports the multigene family premise /GenBank 
Submission numbers: AY845260, AY845261, and AY845262). Our laboratory is currently conducting research on the large-scale production of recombinant Mefp-2 protein (Silverman and Roberto 2006b).

As is the case with Mefp-1, other mussel species contain proteins analogous to Mefp-2: $M$. galloprovincialis (Mgfp-2) (Inoue et al. 1995b); $M$. coruscus (Mcfp-2) (Inoue et al. 2000); and D. polymorpha (Dpfp-2) (Rzepecki and Waite 1993). Stewart et al. (2004) reported that the tube cement of Phragmatopoma californica, a marine polychaete, forms solid foam (similar to Mefp-2) via cross-linking with DOPA.

Mefp-3. Mefp-3 is the smallest byssal adhesive protein identified to date, with a molecular mass of $\sim 5$ to $7 \mathrm{kDa}$ (Papov et al. 1995; Warner and Waite 1999). Mefp-3 contains no repeats, 20 to $25 \mathrm{~mol} \%$ DOPA, and a prevalence of 4-hydroxyarginine and tryptophan residues. Warner and Waite (1999) identified 20 gene variants $(\sim 0.3 \mathrm{kB})$ of Mefp-3 in the foot organ; however, only four or five proteins have actually been detected in plaques deposited on glass or plastic. The presence of a gene family for Mefp-3 supports the primer-like function proposed for the protein in adhering to substrata. One hypothesis has been that deposition of a specific Mefp-3 variant is dependent on the surface used for attachment. However, Floriolli et al. (2000) reported no correlation between Mefp-3 expression and surface type (stainless steel, glass, polyethylene) in an individual mussel. Differences in cDNA transcripts were found between animals. Zhao et al. (2006) reported 12 different Mcfp-3 variants from a mussel population-broken into "fast" or "slow" electrophoretic characteristics-upon exposure to glass coverslips. The molecular mechanism(s) for the numerous Mefp-3 and Mcfp-3 variants is not known. Variables, such as exposure time to surfaces, water temperature, and the age of the animals, could influence expression levels.

As is the case with Mefp-1 and Mefp-2, other mussel species contain proteins analogous to Mefp-3 variants: M. galloprovincialis (Mgfp-3A and Mgfp-3B) (Inoue et al. 1996a) and M. californianus (Mcfp-3-12 variants, mentioned above) (Zhao et al. 2006).

Mefp-4. Mefp-4 is another protein identified in byssal plaques, with a molecular mass of $79 \mathrm{kDa}$ (Weaver 1998; Vreeland et al. 1998; Warner and Waite 1999). Mefp-4 contains elevated levels of glycine, arginine, and histidine, as well as $4 \mathrm{~mol} \%$ DOPA. A unique tyrosine-rich octapeptide is present, with variations in residue substitutions giving rise to a family of proteins. This very large protein most likely serves as a coupling agent in the thread-plaque junction designated by the precollagens and the byssal plaque protein Mefp-2. A gene sequence for Mefp- 4 has not been identified; however, two-foot protein variants from $M$. californianus have recently been identified (Mcfp4; Zhao and Waite 2006a).

Mefp-5. Mefp-5 is the most recent adhesive-related byssal plaque protein identified from Mytilus edulis (Waite and Qin 2001). Mefp-5 is a relatively small protein with a molecular mass of $9.5 \mathrm{kDa}$, a $27 \mathrm{~mol} \%$ DOPA content, and the presence of phosphoserine. Phosphoserine is known to occur in acidic mineralbinding motifs of proteins that bind calcareous materials (e.g., osteopontin); therefore, its presence in byssal plaques may aid in adhesion of one animal to a neighboring mussel's shell. Mefp-5 was formerly associated with the Mefp-3 family of variants, and similarly, plays an interfacial role as a primer for substrate adhesion. An adhesive protein analogous to Mefp-5 has recently been reported to be present in $M$. galloprovincialis (Mgfp-5) (Hwang et al. 2004) and $M$. californianus (Mcfp-5-2 variants) (Zhao and Waite 2006b).

\section{Discovery of Additional Foot Proteins: Mcfp-} 6. Mcfp- 6 was identified along with Mcfp-5 by Zhao and Waite (2006b; 3 variants). This small protein $(11.6 \mathrm{kDa})$ contains a relatively large amount of tyrosine and a small amount of DOPA. Its suggested role in adhesion may be to provide a link between the DOPA-rich proteins and the plaque proteins present in byssal attachment plaques.

\section{Adhesive Testing of Mussel Proteins}

A wide variety of adhesive tests have been applied to intact byssal threads, plaque, portions of threads, or materials bonded or coated with individual adhesive proteins. Gross comparative tests on byssal threads were described earlier in this review.

Mussels seem to prefer surfaces with higher critical surface energy, a phenomenon also observed in barnacles (Crisp et al. 1985; Waite 1987). Plaques were shown to attach more strongly to slate and glass than plastic acetal (acetate), paraffin wax, and polytetrafluoroethylene (PTFE). The high-energy, hydrophilic surfaces (glass, slate) had smaller plaque surfaces attached to substrates and smaller contact angles compared with the low-energy, hydrophobic surfaces (wax, PTFE).

Attachment Failure. Byssal attachments can fail in a number of ways. A byssal plaque can 
cleanly peel away from a surface, the byssal thread itself can tear or fail, or the root can tear away from the animal. Failure of the thread is the most common cause of failure of byssal attachment. If byssal threads break or tear away from the animal, the true adhesive force is underestimated. Therefore, when analyzing adhesive forces, it is important to consider the type of failure. The surface for attachment, source of foot protein, age of animal, temperature, and season are important in evaluating the strength of byssal attachments (Crisp et al. 1985).

Adhesive Techniques. Numerous surfaces and techniques are used to evaluate the mechanical properties of mussel adhesive proteins. Atomic force microscopy (AFM; for surface topography), attenuated total reflection fourier transform infrared spectroscopy (ATR/FT-IR; for information on molecular composition, bonding, conformation and orientation with respect to interfaces), surface plasmon resonance $\left(\mathrm{SPR}_{\text {; }}\right.$ to study interactions of samples and surfaces), and tensometer methods (for tensile strength and elastic properties) are common techniques used in adhesives research. Table 2 provides examples of studies in which surfaces have been tested with mussel adhesive proteins or synthetic analogs containing repetitive motifs from mussel proteins

Brazee and Carrington (2006) recently provided an elegant and detailed study of whole byssal thread material properties comparing threads from a range of Mytilidae. This study also compared their results to those of previous studies, along with statistics to quantify the variation in the results. Quasi-static tensile strength tests and dynamic testing of elastic properties (extensibility, modulus, resilience, and recovery) were performed and correlated with morphometric measurements, including shell weight and dimensions, and thread morphometry. Several interesting findings were reported, including the elliptical cross-section (rather than a regular, round section) of the byssal thread, novel behavior of Modiolus modiolus threads ("double yield" under strain), the surprising strength of Dreissena polymorpha threads (although they lack a collagen core), and the overall greater strength of Mytilis californianus threads (suggested to be a factor in its success in living in the strong tidal environment of the Pacific coast).

The application of atomic force microscopy (AFM) is revolutionizing our understanding of the interactions of mussel adhesive proteins with surfaces and with other adhesive proteins that make up the byssal thread. It is now possible to measure adhesion energy and shear forces of individual adhesive proteins, such as has been done in comparing $M$. edulis foot proteins 1 and 3 (Lin et al. 2007). Even more remarkably, the cantilevers of an AFM can be coated with DOPA residues to perform single molecule measurements and quantify the differences in bond strength that might be expected between unmodified and DOPA-modified adhesives (Lee et al. 2006).

As our ability to perform sensitive measurements with small amounts of protein improves, along with the increased resolution of the techniques used, we can anticipate that our understanding of the interactions of adhesive proteins necessary to achieve robust adhesion will increase.

\section{Future Supply of Adhesive Proteins by Recombinant Approaches}

Background. An impediment to further understanding the unique adhesion system of $M$. edulis is the lack of availability of the individual protein components. Large quantities of $M$. edulis (or other mussel) adhesive proteins are needed to perform research and development for commercial adhesives. Current methods for obtaining the adhesive proteins of the mussel byssus rely largely on excision of the byssus followed by extraction of the proteins under acidic conditions. However, the chemical extraction process does not always yield pure or individual adhesive proteins. Approximately 10,000 M. edulis mussels are needed to produce $1 \mathrm{~g}$ of Mefp-1 adhesive from byssal structures (Strausberg and Link 1990; Hwang et al. 2007a). At least $100 \mathrm{mg}$ of material is needed for performing small, conventional adhesive tests, such as tensile strength or wall-jet analyses. The sacrifice of such a large number of animals is neither environmentally friendly nor economically practical. Therefore, an alternate approach to obtain large amounts of adhesive protein components is necessary for further conventional adhesive testing formats and adhesive formulation development. Molecular and microbiology techniques can be used for the directed production of large quantities of many different proteins.

Prokaryotes and eukaryotes are used as hosts in recombinant protein expression systems. Common prokaryote hosts include bacteria (Escherichia coli), Saccharomyces cerevisiae (baker's yeast), Pichia pastoris (a methylotrophic yeast), or Kluyveromyces lactis (a lactic-acid-producing yeast). Eukaryote hosts include plants (tobacco, potatoes), trees (loblolly-pine), and mammals (rabbit, mouse, goat). Cell culture techniques use insect, plant, and mammalian cells or tissue cultures rather than whole organ- 


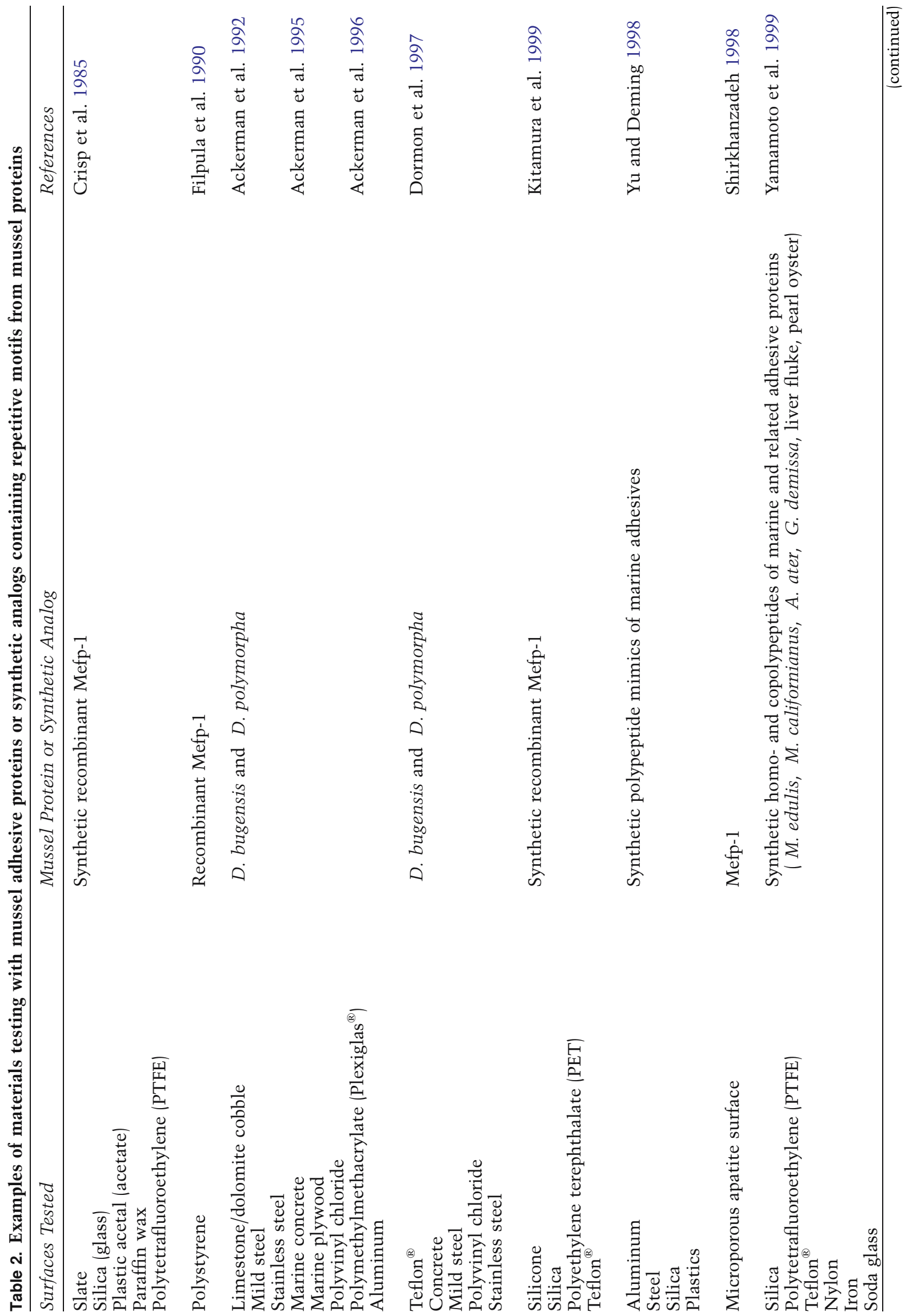




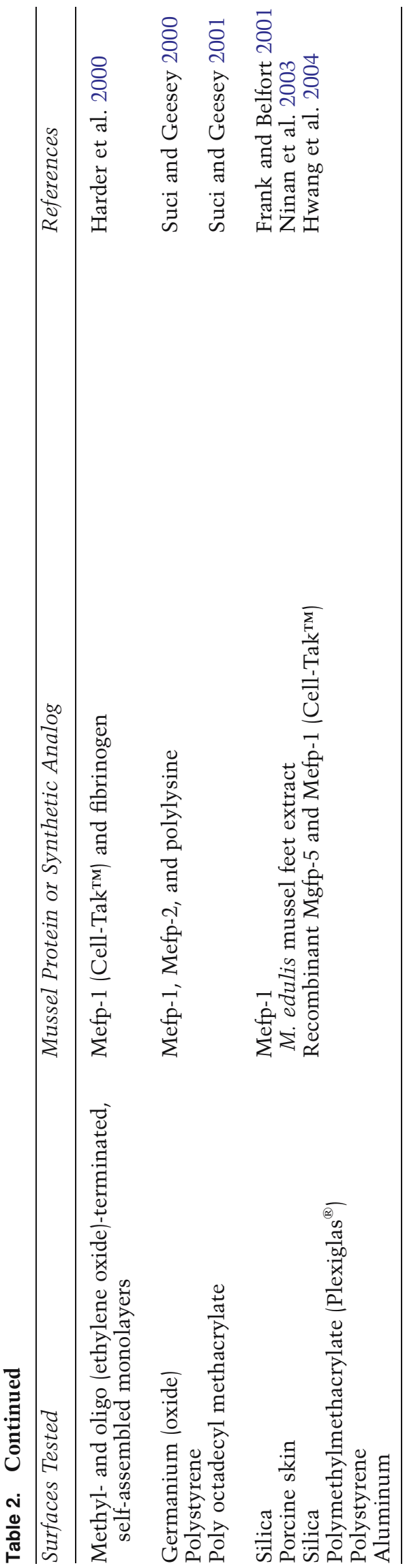

isms. Variables important for successful recombinant protein expression systems include a codonusage-compatible host; promoter, transcriptional, and translational regulators; fine-tuned cultivation methods; targeted recombinant protein purification methodologies; posttranslational modification ability; and three-dimensional configuration of the recombinant protein.

Codon usage refers to the predominant DNA bases that code for specific amino acids. Codon analysis can be performed for the source organism across all its known proteins or only for the specific protein or protein class of interest. Possible choices for mussel adhesive recombinant protein expression include a eukaryotic host, a special bacterial line (E. coli BL21 strains), or a plant source, such as tobacco (because plant cell wall proteins are repetitive proteins with hydroxylations).

Promoter and transcriptional regulators are DNA sequences that direct gene expression. They can be native to the host, artificially added to the host DNA, or incorporated in vector systems. Translational stop signals can be incorporated into the DNA genes or are present on an expression vector. Prokaryotes and eukaryotes use different regulators for gene expression.

Cultivation factors, such as energy sources, aeration (oxygen), temperature, and induction protocols are specific to the host organism or cell type and are dependent on the quantity used for production. Small-scale cultivation generally involves flasks or petri dishes and volumes less than $1 \mathrm{~L}$. Larger-scale cultivation in the research laboratory setting can use bioreactors with volumes as large as 100 L. Automated monitoring and control of cultivation variables is used in large-scale recombinant protein production.

Heterologous recombinant protein production occurs simultaneously with the host's production of its own proteins. Thus, harvesting of a recombinant protein involves its identification and separation from the host's native proteins. Special tags that can be incorporated with a recombinant protein include specific amino acid repeats (histidine), fluorescent molecules (green fluorescent protein), biotinylation, or antibody recognition sequences (epitopes). The specific chemical properties of proteins also can be used for isolation and purification. For $M$. edulis adhesive proteins Mefp-1 and Mefp-2, acidic conditions in purification steps will exclude many of the host's native proteins while maintaining the integrity of the mussel proteins.

One caveat in heterologous protein production, however, is that correctly folded or modified proteins are not always produced. Prokaryotes and 
eukaryotes can modify their proteins following translation with specific disulfide bond formation for correct protein folding, cleavage of precursor protein forms to yield functional proteins, glycosylation of amino acid residues for protein stability, and other modifications to amino acids, such as phosphorylation, acetylation, or hydroxylation (as in the case with many $M$. edulis adhesive proteins). Posttranslational modifications do not always occur naturally in heterologous systems; therefore, in vitro methods often are required to obtain properly modified proteins. For example, heterologously produced, unhydroxylated Mefp-1 requires treatment with mushroom or bacterial tyrosinase to produce hydroxylated tyrosine (DOPA) at positions two and nine of the decapeptide repeat (Strausberg and Link 1990; Filpula et al. 1990; Kitamura et al. 1999). Other considerations for biologically functional, recombinant proteins include hyperglycosylation, inclusion bodies, and loss of expression plasmids with a scale-up in cultivation volumes.

The Recombinant Protein Approach. The recombinant expression of cDNAs or synthetic adhesive-related proteins modeled from organisms other than mussels has been reported: human blood coagulation protein Factor XIIIa in the yeast $S$. cerevisiae (Broker et al. 1991) and collagen and spider silk proteins in bacteria, yeast, insect, and mammalian cells and plants (Fahnestock et al. 2000; Kieliszewski and Lamport 1994; Scheller et al. 2001).

Researchers have, to some extent, successfully produced Mytilus mussel adhesive proteins in bacteria, yeast, mammalian cells, and plants. Filpula et al. (1990) used a hybrid combination of promoters to direct the production of Mefp-1-like tandem repeats in S. cerevisiae. A single copy of the genomic cDNA clone for Mefp-1 encoded the carboxy terminus, including 19 decapeptide and one hexapeptide repeat sequences. Synthetic gene constructs carrying between one and four copies of a portion of the genomic sequence for Mefp-1 were shown to express proteins between 20 to $100 \mathrm{kDa}$. Amino acid analyses of the four different recombinant proteins expressed in the yeast system were similar to unhydroxylated natural Mefp- 1 . The recombinant protein constituted $2 \%$ to $5 \%$ of the total cell protein, and adhesive tests showed water-resistant bonding after in vitro modification of tyrosine residues to DOPA and then quinone. Salerno and Goldberg (1993) expressed a synthetic mussel adhesive protein analog in E. coli using a $\mathrm{T} 7$ promoter system and a repetitive gene cassette that encoded the consensus decapeptide repeat of Mefp-1. The synthetic polydecapeptide was produced from a 600 base pair gene (20 decapeptide repeats) and constituted up to $60 \%$ of total cell protein. Kitamura et al. (1999) also expressed a synthetic mussel adhesive protein analog in E. coli with a $\mathrm{T} 7$ promoter system and a repetitive gene cassette that encoded six repeats of the consensus decapeptide of Mefp-1. The researchers were able to obtain $10 \mathrm{mg}$ of the model peptide per liter of growth medium. Surface strength and contact-angle were measured and used to calculate the value of work of adhesion $\left(\mathrm{W}_{\mathrm{A}}\right)$ for both the unmodified and mushroom-tyrosinase-treated peptide. Adhesion to silicone, glass, polyethylene terephthalate, and Teflon ${ }^{\circledR}$ substrates was found to be dependent on sodium chloride concentration (e.g., sea water).

Our laboratory has patented a technique for cloning and expressing recombinant Mefp-1 and Mefp-2 in S. cerevisiae from cDNA clones (Silverman and Roberto 2006a, b). We are currently producing rMefp-1, rMefp-2, and rMefp-3 in 20-L fermentation batches (unpublished data). Purification of each individual recombinant protein is in progress. The purified products will be analyzed by mass spectrometry (MS) for total intact mass followed by MS analysis (post-protease digestion). Adhesive studies will be performed in-house and/or through interested parties after the confirmation of rMefp-1, rMefp-2, and rMefp-3.

Recombinant mussel adhesive proteins from $M$. galloprovincialis also have been produced. Takeuchi et al. (1999) cultured mussel foot cells from $M$. galloprovincialis in Petri dishes. Gene-specific probes were used to identify the stage of development for different adhesive proteins. Probes for the genes encoding Mgfp-1, -2, and -3 were used to demonstrate that the expression of the byssal protein genes in M. galloprovincialis is morphologically programmed (Takeuchi et al. 1997). The findings suggested that a cell culture system for in vitro expression of byssal adhesive proteins might be a plausible alternative to yeast- or bacterial-based expression systems.

Hwang et al. (2004) produced a soluble, recombinant Mgfp-5 fused with a histidine tag in E. coli. A purification yield of $\sim 7 \%$ was obtained from a $3 \mathrm{~L}$ working volume because of difficulties in removing the recombinant protein from the chromatographic resin used to bind histidine proteins. The adhesive properties of recombinant Mgfp- 5 were compared to Cell-Tak ${ }^{\mathrm{TM}}$ by using atomic force microscopy (AFM) , material surface coating (on glass, polymethylmethacrylate, polystyrene, a silicone-based antifouling agent-coated slide, and aluminum), and quartz crystal microbalance (QCM) techniques. Recombinant Mgfp5 was shown to have adhesive abilities comparable to-and sometimes exceeding-those of Cell-Tak ${ }^{\mathrm{TM}}$. 
The adhesion force of tyrosinase-treated Mgfp-5 ( 981 nN) was higher than both tyrosinase-treated Cell-Tak ${ }^{\mathrm{TM}}(\sim 302 \mathrm{nN})$ and untreated Cell-Tak ${ }^{\mathrm{TM}}$ $(\sim 624 \mathrm{nN})$. The adhesion ability of recombinant Mgfp-5 to a glass slide and a poly-(methyl methacrylate) plate was comparable to Cell-Tak ${ }^{\mathrm{TM}}$ but better than Cell-Tak ${ }^{\mathrm{TM}}$ on a silicone-based antifouling agent coated slide. And, adsorption of Mgfp-5 to a gold surface was comparable to Cell-Tak ${ }^{\mathrm{TM}}$.

Hwang et al. (2005) also produced recombinant Mgfp-3 (variant A) with a histidine tag in E. coli. The purification yield and solubility exceeded that of the above-mentioned recombinant Mgfp-5. The adsorption and adhesion force were comparable to CellTak ${ }^{\text {TM }}$ but less than recombinant Mgfp-5 (e.g. $\sim 230 \mathrm{nN}$ for Mgfp-3, $240 \mathrm{nN}$ for Cell-Tak ${ }^{\mathrm{TM}}$, and $\sim 550 \mathrm{nN}$ for Mgfp-5).

Hwang and colleagues noted the low production yields, low purification yields, and high levels of insolubility of rMgfp-3 and rMgfp-5 and sought to improve the technique for recombinant protein expression by designing novel fusion proteins (Hwang et al. 2007a, b). The first hybrid MAP mussel bioadhesive-fp-151-was produced from a fusion protein containing six Mgfp-1 decapeptide repeats at both the $\mathrm{N}$ - and C-termini of Mgfp-5 (Hwang et al. 2007a). The second hybrid MAP mussel bioadhesive-fp-151-RGD—was a fusion of the GRGDSP residues found in fibronectin (designated RGD) to the C-terminus of fp-151 (Hwang et al. 2007b). The authors reported greater production yields, easier purification, and improved solubility for both novel fusion proteins fp-151 and fp-151-RGD. In addition, the cell adhesion and spreading abilities of fp-151-RGD were superior to Cell-TakTM, polyL-lysine (PLL), a noncoated surface, and fp-151regardless of mammalian cell type tested (human or hamster).

The first non-Mytilus recombinant mussel adhesive protein, the Mefp-1-like adhesive protein Dpfp-1 from the zebra mussel D. polymorpha, was expressed by Anderson and Waite (2000). Recombinant Dpfp-1 was produced as a maltose-fusion protein in E. coli. The recombinant protein was then used as an antigen for polyclonal antibody production. Immunologic studies definitively revealed the presence of Dpfp-1 in foot organs and byssal threads of $D$. polymorpha.

Whole plants have been used to synthesize foreign/recombinant proteins, such as antibodies, vaccines, and industrial enzymes (Doran 2000). An alternative to the use of whole plants is the use of plant tissue cultures. Tissue cultures provide a technology that may gain momentum because of the ease in manipulation of culture conditions for greater foreign protein levels. There is considerable expense in cell culture techniques, indicating that this scheme would not be optimal for industrial production. Tobacco and rice are the most commonly used plant cell cultures used to date. Correct posttranslational modification is an issue when using plants as hosts, similar to bacterial or yeast expression systems.

However, plants may be very good hosts for production of the repetitive mussel adhesive proteins. Plant cell walls contain large, repetitive proteins similar to foot protein-1 analogs and the diverse collagens found in byssal threads. Dr. Simon McQueen-Mason (Department of Biology, University of York, United Kingdom) has investigated the ability of transgenic tobacco plants to produce recombinant spider silks and Mgfp-1 because of their similarity to the repetitive plant cell wall proteins expansin and extensin (http://www.cnap. org.uk/). His group continues to research expansins and pectins from various plant species (Jones et al. 2005). Recently, Patel et al. (2007) reported the use of elastin-like polypeptide fusions (an ELP tag) to enhance the accumulation of a range of different recombinant proteins (human interleukin-10, murine interleukin-4, and the native major ampullate spidroin protein 2 gene from the spider Nephilla clavipes) in the leaves of a transgenic tobacco plant. The fusion protein concentrations in the plant leaves were significantly higher than the target recombinant proteins alone in all instances, suggesting that this type of fusion tag may be beneficial for producing large, repetitive recombinant proteins in plant hosts.

\section{Current and Future Research Areas Related to Mussel Adhesion and Adhesives}

Commercialization of Mussel Adhesive Proteins. Numerous economic factors are important in the production and synthesis of foreign proteins, whether using microbial cell culture, animal cell culture, plant tissue culture, transgenic plants, or transgenic animals. Production costs (yield for cost comparisons), safety issues (for therapeutic use), and stability of the product (the potential for the protein to degrade or lose function during extraction/purification procedures) are a few issues that require careful analysis before the method is chosen. Regulatory issues relevant to Good Manufacturing Practice (GMP) for production of therapeutic proteins must be followed. Any product containing recombinant mussel adhesive protein will require extensive testing and validation from health, environmental, and adhesives industries before commercialization. 
The underwater adhesion of the marine mussel, $M$. edulis, has intrigued scientists for decades. Extensive progress has been made in elucidating the mechanisms responsible for adhesion, in understanding adhesion to a variety of substrates, and in producing recombinant proteins and materials that mimic the natural mussel adhesive. A selection of current and future research areas related to mussel adhesives is discussed below.
Biofouling. In 1987, mussel biofouling cost the Navy more than $\$ 200 \mathrm{M}$ in the areas of hull scraping and excess fuel consumption from unnecessary drag on large vessels (Morgan 1990). Understandably, the Office of Naval Research and other organizations have invested considerably in the areas of antifouling and foul-release. Approaches to antifouling and bivalve control can generally be classified as chemical or physical (hull scraping) methodologies.

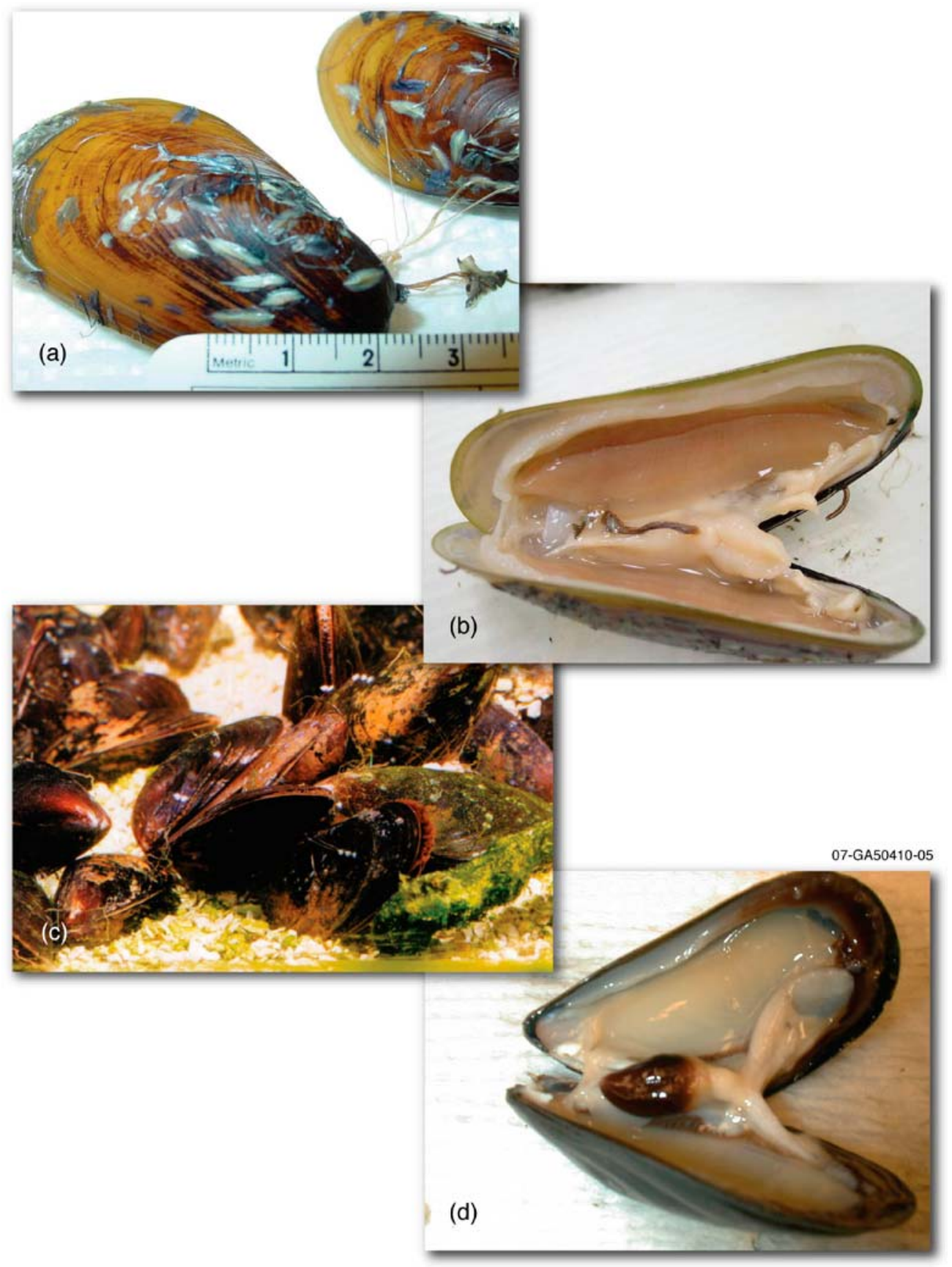

Figure 5. Gross appearance and internal organs of B. childressi and M. edulis mussels: (a) B. childressi shell, thread, and plaques, (b) B. childressi foot organ, (c) M. edulis shell, thread, and plaques, (d) M. edulis foot organ. 
Chemical methods have received the most attention. Until recently, bis(tributyltin)oxide was a popular antifouling component of boat paints. However, heavy metal-based and organotin coatings are now restricted because they are toxic to marine and freshwater organisms. Synthetic and natural biodegradable compounds are currently being investigated for their efficacy as antifouling agents. Imides (special types of amino acid-based compounds), terpenoids (multicyclic structures with basic carbon skeletons) from brown alga species and a marine sponge, proteases from a marine bacterium, phloroglucinol compounds (white, crystalline phenols) from Eucalyptus, and a variety of chemicals have all been shown to inhibit mussel attachment to surfaces (Zentz et al. 2001; Hellio et al. 2001; Sera et al. 1999; Venkateswaran and Dohmoto 2000; Cope et al. 1997). Experimentation with low-adhesion surfaces has included modified glass (Yamamoto et al. 1997), polyethylene glycol (PEG) (Dalsin et al. 2003), and various other polymeric surfaces (Frank and Belfort 2001). Antifouling and detachment research related to mussels and other sessile organisms is vitally important in addressing the economical problems associated with biofouling (Taylor 2006; Bellas 2006; Bellas et al. 2005).

Mussels from Extreme Environments. Hydrothermal vents and cold seeps from the Gulf of Mexico and the Japan Trench are home to unique combinations of sea life. New classes of animals, plants, and bacteria are rapidly being identified with the aid of special underwater submersibles (ALVIN, the Johnson Sea Link) and advances in molecular biology and microbiology. Bathymodiolinae is a subfamily of mussels that contains species harboring methanotrophic, chemoautotrophic, and/or both types of bacterial endosymbionts within the mussel's gill tissue. Geological forces have caused cracks in the continental slope, allowing oil, natural gases, such as methane and hydrogen sulfide, and related substances to seep into the ocean environments. Bathymodiolinae mussels and other organisms from the Gulf of Mexico have been able to survive under anoxic, high-pressure, and high-saline (brine) environments for centuries. Figure 5 illustrates the large shells and byssal plaques and threads from Bathymodiolus childressi mussels obtained by Dr. Charles Fisher from Brine Pool NR1 in the Gulf of Mexico (MacDonald and Fisher 1996) compared with $M$. edulis (Figure 5a and c). The foot organs of $M$. edulis and $B$. childressi and $M$. edulis (Figure $5 \mathrm{~b}$ and d) also are shown for comparison. The morphologic differences in the foot organ, shell, and gill characteristics between the two marine mussel species, as well as the vast differences between the environmental conditions in which the two reside, may be important variables affecting byssus characteristics (material properties, adhesion mechanisms, individual proteins, etc.; Brazee and Carrington 2006). The identification of adhesive proteins from extreme mussels is an interesting task for prospective research.

Novel Applications for Mussel Adhesive Collagens and Polyphenol Oxidase. Immobilization of mussel adhesive proteins (Mefp class and collagens) on solid supports may be exploited for uses in the design of biosensors, immunosensors, or artificial tissue scaffoldings and constructs: Mefp-1 with glucose (Saby and Luong 1998; Newman and Setford 2006), Mefp-1 with human chorionic gonadotrophin (Burzio et al. 1996), collagens as supports $\left(\mathrm{BD}^{\mathrm{TM}}\right.$ Three-Dimensional Collagen Composite Scaffold; BD Biosciences; San Jose, CA). The identification and subsequent use of the polyphenol oxidase derived from $M$. edulis byssal structures also could be exploited as a thickening agent for numerous industries/applications (Yamada et al. 2000).

Medical and Dental Adhesives. Current adhesives approved for medical use in the United States include fibrin sealants, albumin-based compounds, glutaraldehyde glues, cyanoacrylates, hydrogels, and collagen-based compounds. Fibrin sealants are the most prevalent. They consist primarily of thrombin and fibrinogen, clotting factors in blood. Fibrin sealants have a wide range of uses and are bioabsorbed by the body. However, risks of products isolated from blood, albeit minimal, are a concern with this class of tissue adhesives. One albumin-based compound approved for use in the United States is BioGlue ${ }^{\circledR}$ Surgical Adhesive (CryoLife Inc.; Kennesaw, GA). It is glutaraldehyde-based, or gelatin-resorcinolformaldehyde-glutaraldehyde-like, glue (without the formaldehyde) that has limited U.S. Food and Drug Administration approval because of known immunoreactivity problems. The cyanoacrylates approved for use in the United States are stronger than the fibrin sealants but not bioabsorbable. Their use is restricted to external or temporary applications because of associations with carcinogenicity, inflammation, and infection. Hydrogels are watersoluble polyethylene glycol polymers that are activated by light. Both protein-based and DOPAbased hydrogel formulations are being researched (Nowak et al. 2002; Mo et al. 2006; Liu and Li 2002). Currently, their use is limited because of 
the time required for application, setting, and bioabsorption.

Collagen-based adhesives are the newest type of tissue adhesive available (Koob and Hernandez 2002). So far they work well and are inexpensive, thus adding an alternative to the use of fibrin sealants. Dr. Robin L. Garrell (Organic Chemistry Department, University of California, Los Angeles [UCLA]) has worked on elucidating the chemical mechanisms for adhesion and cohesion in Mefp-1 and other marine biopolymers to develop artificial tissues and bioreactors (Ooka and Garrell 2000; http://www.chem.ucla.edu/dept/Organic/garrell. html). Future dental and medical adhesives may contain mussel adhesive proteins and/or domains from mussel adhesives (Tay and Pashley 2002; Ninan et al. 2003; Fulkerson et al. 1990; Robin et al. 1988; Schmidt et al. 1994).

\section{Conclusions}

Scientists and laymen alike have been fascinated for years with the ability of mussels to cling to surfaces under water. The ability to adhere in an aqueous environment, withstand numerous environmental forces, and resist conventional approaches to detachment are factors that continue to intrigue researchers today. During the last two decades, considerable time and effort has been spent in identifying the proteins that contribute to underwater adhesion by marine mussels. The production-scale availability of recombinant mussel adhesive proteins will enable researchers to develop formulations for adhesives in which there exist endless applications for the commercialization of water-impervious, ecologically safe adhesives derived from mussels.

\section{Acknowledgements}

This work was supported through funding provided by the U.S. Department of Energy (DOE) to the Idaho National Laboratory, operated by Battelle Energy Alliance, LLC, under DOE Idaho Operations Office Contract DE-AC07-05ID14517. The deep seep Bathymodiolus childressi mussels were a gift from Dr. Charles Fisher of Pennsylvania State University. The mussels were collected with the support of the National Science Foundation OCE 0117050 and National Oceanic and Atmospheric Administration's (NOAA) Ocean Exploration and National Undersea Research Program awards to Dr. Fisher. Special thanks are given to Gordon Holt, Leslie Ovard, Allen Haroldsen, and David Klepich for their assistance in the preparation and review of this manuscript.
U.S. Department of Energy Disclaimer. This information was prepared as an account of work sponsored by an agency of the U.S. Government. Neither the U.S. Government nor any agency thereof, nor any of their employees, makes any warranty, express or implied, or assumes any legal liability or responsibility for the accuracy, completeness, or usefulness of any information, apparatus, product, or process disclosed, or represents that its use would not infringe privately owned rights. References herein to any specific commercial product, process, or service by trade name, trademark, manufacturer, or otherwise, does not necessarily constitute or imply its endorsement, recommendation, or favoring by the U.S. Government or any agency thereof. The views and opinions of authors expressed herein do not necessarily state or reflect those of the U.S. Government or any agency thereof.

\section{References}

Ackerman JD, Ethier CR, Allen DG, Spelt JK (1992) Investigation of Zebra Mussel adhesion strength using rotating-disks. J Environ Eng-ASCE 118, 708

Ackerman JD, Cottrell CM, Ethier CR, Allen DG, Spelt JK (1995) A wall-jet to measure the attachment strength of Zebra Mussels. Can J Fish Aquat Sci 52, 126

Ackerman JD, Cottrell CM, Ethier CR, Allen DG, Spelt JK (1996) Attachment strength of Zebra Mussels on natural, polymeric, and metallic materials. J Environ Eng-ASCE 122, 141

Anderson KE, Waite JH (2000) Immunolocalization of Dpfp-1, a byssal protein of the Zebra Mussel, Dreissena polymorpha. J Exp Biol 203, 3065

Anderson KE, Waite JH (2002) Biochemical characterization of a byssal protein from Dreissena bugensis (Andrusov). Biofouling 18, 37

Arora A, Arora T (2004) Materials for innovative ecoproducts. Mater Technol 19, 153

Bell EC, Gosline JM (1996) Mechanical design of mussel byssus: material yield enhances attachment strength. J Exp Biol 199, 1005

Bellas J (2006) Comparative toxicity of alternative antifouling biocides on embryos and larvae of marine invertebrates. Sci Total Environ 367, 573-585

Bellas J, Granmo K, Beiras R (2005) Embryotoxicity of the antifouling biocide zinc pyrithione to sea urchin ( Paracentrotus lividus) and mussel (Mytilus edulis). Mar Pollut Bull 50, 1382-1385

Brazee SL, Carrington E (2006) Interspecific comparison of the mechanical properties of mussel byssus. Biol Bull 211, 263-274

Broker M, Baume O, Gottig A, Ochs J, Bodenbenner M, Amann E (1991) Expression of the human bloodcoagulation protein factor-XIIIA in Saccharomycescerevisiae - dependence of the expression levels from 
host-vector systems and medium conditions. Appl Microbiol Biot 34, 756-764

Brown CH (1952) Some structural proteins of Mytilus edulis. Q J Microsc Sci 93, 487

Burzio LA (1996) Catechol oxidases associated with byssus formation in the Blue Mussel, Mytilus edulis [master's thesis]. Newark, DE: University of Delaware

Burzio LA, Waite JH (2002) The other TOPA: formation of 3,4,5-trihydroxyphenylalanine in peptides. Anal Biochem 306, 108

Burzio LO, Burzio VA, Silva T, Burzio LA, Pardo J (1997) Environmental bioadhesion: themes and applications. Curr Opin Biotech 8, 309

Burzio VA, Silva T, Pardo J, Burzio LO (1996) Mussel adhesive enhances the immobilization of human chorionic gonadotrophin to a solid support. Anal Biochem 241, 190

Carrington E (2002) Seasonal variation in the attachment strength of Blue Mussels: causes and consequences. Limnol Oceanogr 47, 1723

Coover HW, McIntire JM (1977) "Cyanoacrylate adhesives". In: Handbook of Adhesives, 2nd ed, Skeist I, ed. (New York: Van Nostrand Reinhold Company) pp $569-580$

Cope WG, Bartsch MR, Marking LL (1997) Efficacy of candidate chemicals for preventing attachment of Zebra Mussels ( Dreissena polymorpha). Environ Toxicol Chem 16, 1930

Coyne KJ, Qin XX, Waite JH (1997) Extensible collagen in mussel byssus: a natural block copolymer. Science 277, 1785

Coyne KJ, Waite JH (2000) In search of molecular dovetails in mussel byssus: from the threads to the stem. J Exp Biol 203, 1425

Crisp DI, Walker G, Young GA, Yule AB (1985) Adhesion and substrate choice in mussels and barnacles. J Colloid Interf Sci 104, 40

Dalsin JL, Hu BH, Lee BP, Messersmith PB (2003) Mussel adhesive protein mimetic polymers for the preparation of nonfouling surfaces. J Am Chem Soc 125, 4253

Deming TJ (1999) Mussel byssus and biomolecular materials. Curr Opin Chem Biol 3, 100-105

DeMoor S, Waite JH, Jangoux M, Flammang P (2003) Characterization of the adhesive from cuvierian tubules of the sea cucumber Holothuria forskali (Echinodermata, Holothuroidea). Mar Biotechnol 5, 45

Denny MW (1988) Biology and Mechanics of the Waveswept Environment. (New Jersey: Princeton University Press)

Doran PM (2000) Foreign protein production in plant tissue cultures. Curr Opin Biotech 11, 199-204

Dormon JM, Coish C, Cottrell C, Allen DG, Spelt JK (1997) Modes of byssal failure in forced detachment of Zebra Mussels. J Environ Eng 123, 933

Fahnestock SR, Yao Z, Bedzyk LA (2000) Microbial production of spider silk proteins. Rev Mol Biot 74, 105

Filpula DR, Lee SM, Link RP, Strausberg SL, Strausberg RL (1990) Structural and functional repetition in a marine mussel adhesive protein. Biotechnol Progr 6, 171
Floriolli RY, von Langen I, Waite JH (2000) Marine surfaces and the expression of specific byssal adhesive protein variants in Mytilus. Mar Biotechnol 2, 352

Frank BP, Belfort G (2001) Atomic force microscopy for low-adhesion surfaces: thermodynamic criteria, critical surface, tension, and intermolecular forces. Langmuir 17,1905

Fukuta S, Oyama M, Kavalkovich K, Fu FH, Niyibizi C (1998) Identification of types II, IX, and X collagens at the insertion site of the bovine achilles tendon. Matrix Biol 17, 65

Fulkerson JP, Norton LA, Gronowicz G, Picciaino P, Massicotte JM, Nissen CW (1990) Attachment of epiphyseal cartilage cells and 17/28 rat osterosarcoma osteoblasts using mussel adhesive protein. J Orthopaed Res 8, 793

Guerette P, Ginzinger D, Weber B, Gosline JM (1996) The spider silk fibroin gene family: gland-specific expression controls silk properties. Science 272, 112

Haemers S, van der Leeden MC, Frens G (2005) Coil dimensions of the mussel adhesive protein Mefp-1. Biomaterials 26, 1231

Harder P, Grunze M, Waite JH (2000) Interaction of the adhesive protein Mefp-1 and fibrinogen with methyl and oligo(ethylene glycol)-terminated self-assembled monolayers. J Adhesion 73, 161

Hassenkam T, Gutsmann T, Hansma P, Sagert J, Waite JH (2004) Giant bent-core mesogens in the thread forming process of marine mussels. Biomacromolecules 5, 1351

Hellio C, Bourgougnon N, Le Gal Y (2000) Phenoloxidase (E.C. 1.14.18.1) from the byssus gland of Mytilus edulis: purification, partial characterization, and application for screening products with potential antifouling activities. Biofouling 16, 235-244

Hellio C, Thomas-Guyon H, Culioli G, Piovetti L, Bourgougnon N, Le Gal Y (2001) Marine antifoulants from Bifurcaria bifurcata (Phaeophyceae, Cystoseiraceae) and other brown macroalgae. Biofouling 17, 1889

Hwang DS, Gim Y, Cha HJ (2005) Expression of functional recombinant mussel adhesive protein type $3 \mathrm{~A}$ in Escherichia coli. Biotechnol Progr 21, 965

Hwang DS, Gim Y, Yoo HJ, Cha HJ (2007a) Practical recombinant hybrid mussel bioadhesive fp-151. Biomaterials 28, 3560

Hwang DS, Sim SB, Cha HJ (2007b) Cell adhesion biomaterial based on mussel adhesive protein fused with RGD peptide. Biomaterials 28, 4039

Hwang DS, Yoo HJ, Jun JJ, Moon WK, Cha HJ (2004) Expression of functional recombinant mussel adhesive protein Mgfp-5 in Escherichia coli. Appl Environ Microb 70, 3352

Inoue K, Kamino K, Sasaki F, Odo S, Harayama S (2000) Conservative structure of the plaque matrix protein of mussels in the genus Mytilus. Mar Biotechnol 2, 348

Inoue K, Odo S (1994) The adhesive protein cDNA of Mytilus galloprovincialis encodes decapeptide repeats but no hexapeptide motif. Biol Bull 186, 349

Inoue K, Takeuchi Y, Miki D, Odo S (1995a) Mussel adhesive plaque protein gene is a novel member of epidermal growth factor-like gene family. J Biol Chem 270, 6698 
Inoue $\mathrm{K}$, Takeuchi Y, Miki D, Odo S, Harayama S, Waite $\mathrm{JH}$ (1996a) Cloning, sequencing, and sites of expression of genes for the hydroxyarginine-containing adhesiveplaque protein of the mussel Mytilus galloprovincialis. Eur J Biochem 239, 172

Inoue $\mathrm{K}$, Takeuchi Y, Takeyama S, Yamaha E, Yamazaki F, Odo S, Harayama S (1996b) Adhesive protein cDNA sequence of the mussel Mytilus coruscus and its evolutionary implications. J Mol Evol 43, 348-356

Inoue $\mathrm{K}$, Waite $\mathrm{JH}$, Matsuoka $\mathrm{M}$, Odo $\mathrm{S}$, Harayama $\mathrm{S}$ (1995b) Interspecific variations in adhesive protein sequences of Mytilus edulis, M. galloprovincialis, and M. trossulus. Biol Bull 189, 370

Jones L, Milne JL, McCann MC, McQueen-Mason SJ (2005) A conserved functional role of pectic polymers in stomatal guard cells froma range of plant species. Planta 221, 255

Kamino K, Inoue K, Maruyama T, Takamatsu N, Harayama S, Shizuri Y (2000) Barnacle cement proteins. J Biol Chem 275, 27360

Kieliszewski MJ, Lamport DTA (1994) Extensin - repetitive motifs, functional sites, posttranslational codes, and phylogeny. Plant J 5, 157-172

Kirkpatrick CJ, Wagner M, Kohler H, Bittinger F, Otto M, Klein CL (1997) The cell and molecular biological approach to biomaterial research: a perspective. J Mater Sci-Mater M 8, 131

Kitamura M, Kawakami K, Nakamura N, Tsumoto K, Uchiyama H, Ueda Y, Kumagai I, Nakaya T (1999) Expression of a model peptide of a marine mussel adhesive protein in Escherichia coli and characterization of its structural and functional properties. J Polym Sci 37, 729

Koob TJ, Hernandez DJ (2002) Material properties of polymerized NDGA-collagen composite fibers: development of biologically based tendon constructs. Biomaterials 23, 203-212

Lee H, Scherer NF, Messersmith PB (2006) Singlemolecule mechanics of mussel adhesion. Proc Natl Acad Sci USA 103(35): 12999-13003

Lin Q, Gourdon D, Sun C, Holten-Andersen N, Anderson TH, Waite JH (2007) Adhesion mechanisms of the mussel foot proteins mfp-1 and mfp-3. Proc Natl Acad Sci USA 104, 3782

Liu Y, Li K (2002) Chemical modification of soy protein for wood adhesives. Macromol Rapid Comm 23, 739

Lucas JM, Vaccaro E, Waite JH (2002) A molecular, morphometric, and mechanical comparison of the structural elements of byssus from Mytilus edulis and Mytilus galloprovincialis. J Exp Biol 205, 1807

MacDonald IR, Fisher CR (1996) Life without light. Natl Geogr 190, 313

Mo X, Zhong Z, Wang D, Sun X (2006) Soybean glycinin subunits: characterization of physicochemical and adhesion properties. J Agr Food Chem 54, 7589

Monahan J, Wilker JJ (2003) Specificity of metal ion crosslinking in marine mussel adhesives. Chem Commun 14,1672

Morgan D (1990) Two firms race to derive profits from mussels glue: despite gaps in their knowledge of how the mollusk produces the adhesive, scientists hope to recreate it. Scientist 4,1
Newman JD, Setford SJ (2006) Enzymatic biosensors. Mol Biotechnol 32, 249-268

Ninan L, Monahan J, Stroshine RL, Wilker JJ, Shi RY (2003) Adhesive strength of marine mussel extracts on porcine skin. Biomaterials 24, 4091-4099

Nowak AP, Breedveld V, Pakstis L, Ozbas B, Pine DJ, Pochan D, Deming TJ (2002) Rapidly recovering hydrogel scaffolds from self-assembling diblock copolypeptide amphiphiles. Nature 417, 424-428

Ohkawa K, Nishida A, Ichimiya K, Matsui Y, Nagaya K, Yuasa A, Yamamoto H (1999) Purification and characterization of a DOPA-containing protein from the foot of the Asian Freshwater Mussel, Limnoperna fortunei. Biofouling 14, 181

Ohkawa K, Nishida A, Yamamoto H, Waite JH (2004) A glycosylated byssal precursor protein from the Green Mussel, Perna viridis, with modified DOPA sidechains. Biofouling 20, 101

Olivieri MP, Wollman RM, Hurley MI, Swartz MF (2002) Using conformational analysis to identify structurally conserved regions of MAP peptides that exhibit cellular attachment ability. Biofouling 18, 149

Ooka AA, Garrell RL (2000) Surface-enhanced Raman spectroscopy of DOPA-containing peptides related to adhesive protein of marine mussel, Mytilus edulis. Biopolymers 57, 92-102

Papov VV, Diamond TV, Biemann K, Waite JH (1995) Hydroxyarginine-containing polyphenolic proteins in the adhesive plaques of the marine mussel Mytilus edulis. J Biol Chem 270, 20183

Pardo J, Gutierrez E, Saez C, Brito M, Burzio LO (1990) Purification of adhesive proteins from mussels. Protein Expres Purif 1, 147

Patel J, Zhu H, Menassa R, Gyenis L, Richman A, Brandle J (2007) Elastin-like polypeptide fusions enhance the accumulation of recombinant proteins in tobacco leaves. Transgenic Res 16, 239

Piruzian ES, Bugush VG, Sidoru KV, Goldenkova IV, Mysiychuk KA, Debabov VG (2003) Construction of synthetic genes for analogs of spider silk spidroin 1 and their expression in tobacco plants. Mol Biol+ 37,554

Qin XX, Waite JH (1995) Exotic collagen gradients in the byssus of the mussel Mytilus edulis. J Exp Biol 198, 633

Qin XX, Waite JH (1998) A potential mediator of collagenous block copolymer gradients in mussel byssal threads. Proc Natl Acad Sci USA 95, 10517

Robin JB, Picciano P, Kusleika RS, Salazar J, Benedict C (1988) Preliminary evaluation of the use of mussel adhesive protein in experimental epikeratoplasty. Arch Ophthalmol-Chic 106, 973

Rzepecki LM, Chin SS, Waite JH, Lavin MF (1991) Molecular diversity of marine glues: polyphenolic proteins from five mussel species. Mol Mar Biol Biotech 1, 78-88

Rzepecki LM, Hansen KM, Waite JH (1992) Characterization of cystine-rich polyphenolic protein family from the Blue Mussel, Mytilus edulis-L. Biol Bull 183, 123

Rzepecki LM, Waite JH (1993) The byssus of the Zebra Mussel, Dreissena polymorpha $I I$ : structure and 
polymorphism of byssal polyphenolic protein families. Mol Mar Biol Biotech 2, 267

Saby C, Luong JHT (1998) Mytilus edulis Adhesive Protein (MAP) as an enzyme immobilization matrix in the fabrication of enzyme-based electrodes. Electroanal 10, 1193

Saez C, Pardo J, Gutierrez E, Brito M, Burzio LO (1991) Immunological studies of the polyphenolic proteins of mussels. Comp Biochem Phys B 98, 569

Salerno AJ, Goldberg I (1993) Cloning, expression, and characterization of a synthetic analog to the bioadhesive precursor protein of the sea mussel Mytilus edulis. Appl Microbiol Biot 39, 221

Savla M (1977) "Epoxy resin adhesives." In: Handbook of Adhesives, 2nd ed, Skeist I, ed. (New York: Van Nostrand Reinhold Company) pp 434-445

Scheller J, Guhrs KH, Frosse F, Conrad U (2001) Production of spider silk proteins in tobacco and potato. Nat Biotechnol 19, 573-577

Schmidt SP, Resser JR, Sims RL, Mullins DL, Smith DJ (1994) The combined effects of Glycyl-L-Histidyl-LLysine-Copper (II) and Cell-Tak ${ }^{\mathrm{TM}}$ on the healing of linear incision wounds. Wounds 6, 62

Sera Y, Adachi K, Nishida F, Shizuri Y (1999) A new sesquiterpene as an antifouling substance from a Palauan Marine Sponge, Dysidea herbacea. J Nat Prod 62, 395

Sever MJ, Weisser JT, Monahan M, Srinivasan S, Wilker JJ (2004) Metal-mediated cross-linking in the generation of a marine-mussel adhesive. Angew Chem Int Ed 43, 448

Shirkhanzadeh M (1998) Interaction between self-asembled protein vesicles and microporous apatite surface. J Mater Sci-Mater M 9, 503

Silverman HG, Roberto FF (2006a) Cloning and expression of recombinant adhesive protein Mefp-1 of the Blue Mussel, Mytilus edulis. US6987170B. Patent to Idaho National Laboratory

Silverman HG, Roberto FF (2006b) Cloning and expression of recombinant adhesive protein Mefp-2 of the Blue Mussel, Mytilus edulis. US6995012B1. Patent to Idaho National Laboratory

Smeathers JE, Vincent JFV (1979) Mechanical properties of mussel byssus threads. J Mollus Stud 45, 219

Stewart RJ, Weaver JC, Morse DE, Waite JH (2004) The tube cement of Phragmatopoma californica: a solid foam. J Exp Biol 207, 4727-4734

Strausberg RL, Link RP (1990) Protein-based medical adhesives. Trends Biotechnol 8, 53-57

Suci PA, Geesey GG (2000) Influence of sodium periodate and tyrosinase on binding of alginate to adlayers of Mytilus edulis Foot Protein 1. J Colloid Interf Sci 230, 340

Suci PA, Geesey GG (2001) Comparison of adsorption behavior of two Mytilus edulis foot proteins on three surfaces. Colloid Surface B 22, 159-168

Sun C, Lucas JM, Waite JH (2002) Collagen-binding matrix proteins from elastomeric extraorganismic byssal fibers. Biomacromolecules 3, 1240

Sun C, Waite JH (2005) Mapping chemical gradients within and along a fibrous structural tissue, mussel byssal theads. J Biol Chem 280, 39322
Takeuchi Y, Inoue K, Miki D, Odo S, Harayama S (1997) Expression of two major byssal protein genes during larval development of the mussel Mytilus galloprovincialis. Fisheries Sci 63, 648-649

Takeuchi Y, Inoue K, Miki D, Odo S, Harayama S (1999) Cultured mussel foot cells expressing byssal protein genes. J Exp Zool 283, 131-136

Tay FR, Pashley DH (2002) Dental adhesives of the future. J Adhes Dent 4, 91

Taylor CJ (2006) The effects of biological fouling control at coastal and estuarine power stations. Mar Pollut Bull 53, 30-48

Tsang PH, Li G, Brun YV, Freund LB, Tang JX (2006) Adhesion of single bacterial cells in the micronewton range. Proc Natl Acad Sci USA 103, 5764

Van Winkle W (1970) Effect of environmental factors on byssal thread formation. Mar Biol 7, 143

Venkateswaran K, Dohmoto N (2000) Pseudoalteromonas peptidolytica sp.nov., a novel marine musselthread-degrading bacterium isolated from the Sea of Japan. Int J Syst Evol Micr 50, 565

Vollrath F (2000) Strength and structure of spiders' silk. Rev Mol Biot 74, 67

Vreeland V, Waite JH, Epstein L (1998) Polyphenols and oxidases in substratum adhesion by marine algae and mussels. J Phycol 34, 1

Waite JH (1983a) "Quinone-tanned scleroproteins." In: The Mollusca. Vol. 1. Metabolic Biochemistry and Molecular Biomechanics, Hochachka PW, ed. (London: Academic Press, Inc.) pp 467-504

Waite JH (1983b) Evidence for a repeating 3,4dihydroxyphenylalanine-containing and hydroxyprolinecontaining decapeptide in the adhesive protein of the mussel Mytilus edulis. J Biol Chem 258, 2911

Waite JH (1985) Catechol oxidase in the byssus of the common mussel, Mytilus edulis L. J Mar Biol Assoc UK 65,359

Waite JH (1986) Mussel glue from Mytilus californianus Conrad: a comparative study. J Comp Physiol B 156, 491

Waite JH (1987) Nature's underwater adhesive specialist. Int J Adhes Adhes 7,9

Waite JH (1990) The phylogeny and chemical diversity of quinone-tanned glues and varnishes. Comp Biochem Phys B 97, 19

Waite JH (1999) Reverse engineering of bioadhesion in marine mussels. Ann NY Acad Sci 875, 301

Waite JH, Hansen DC, Little KT (1989) The glue protein of ribbed mussels (Geukensia demissa): a natural adhesive with some features of collagen. J Comp Physiol B 159, 517

Waite JH, Lichtenegger HC, Stucky GD, Hansma P (2004) Exploring molecular and mechanical gradients in structural bioscaffolds. Biochemistry 43, 7653

Waite JH, Qin XX (2001) Polyphosphoprotein from the adhesive pads of Mytilus edulis. Biochemistry 40, 2887

Waite JH, Qin XX, Coyne KJ (1998) The peculiar collagens of mussel byssus. Matrix Biol 17, 93

Waite JH, Tanzer ML (1981) Polyphenolic substance of Mytilus edulis - novel adhesive containing L-DOPA and hydroxyproline. Science 212, 1038 
Wang YJ, Zheng X, Zhang LH, Ohta Y (2004) Cloning and sequencing of the gene encoding mussel adhesive protein from Mytilus sp JHX-2002. Process Biochem 39, 659

Warner SC, Waite JH (1999) Expression of multiple forms of an adhesive plaque protein in an individual mussel, Mytilus edulis. Mar Biol 134, 729

Weaver JK (1998) Isolation, purification, and partial characterization of a mussel byssal precursor protein, Mytilus edulis foot protein 4 [master's thesis]. Newark, DE: University of Delaware

Wiegemann M (2005) Adhesion in blue mussels (Mytilus edulis) and barnacles (genus Balanus): mechanisms and technical applications. Aquat Sci 67, 166

Worthington V, ed (1993) Worthington Enzyme Manual. Enzymes and related biochemicals. Worthington Biochemical Corporation, 335-338

Yamada K, Chen TH, Kumar G, Vesnovsky O, Topoleski LDT, Payne GF (2000) Chitosan based water-resistant adhesive analogous to mussel glue. Biomacromolecules $1,252-258$

Yamamoto H, Nishida A, Ohkawa K (1999) Wettability and adhesion of marine and related adhesive proteins. Colloid Surface A 149, 553

Yamamoto H, Ogawa T, Nishida A (1997) Studies on quinone cross-linking adhesion mechanism and preparation of antifouling surfaces toward the Blue Mussel. J Mar Biotechnol 5, 133

Yu M, Deming TJ (1998) Synthetic polypeptide mimics of marine adhesives. Macromolecules 31, 4739
Yu M, Hwang J, Deming TJ (1999) Role of L-3,4 dihydroxyphenylalanine in mussel adhesive proteins. J Am Chem Soc 121, 5825

Zentz F, Hellio C, Valla A, De La Broise D, Bremer G, Labia R (2001) Antifouling activities of N-substituted imides: Antimicrobial activities and inhibition of Mytilus edulis phenoloxidase. Mar Biotechnol 4, 431

Zhao H, Robertson NB, Jewhurst SA, Waite JH (2006) Probing the adhesive footprints of Mytilus californianus byssus. J Biol Chem 281, 11090

Zhao H, Sun C, Stewart RJ, Waite JH (2005) Cement proteins of the tube-building polychaete Phragmatopoma californica. J Biol Chem 280, 42938

Zhao H, Waite JH (2005) Coating proteins: Structure and cross-linking in fp-1 from the Green Shell mussel, Perna canaliculus. Biochemistry-US 44, 15915

Zhao H, Waite JH (2006a) Proteins in load-bearing junctions: the histidine-rich metal-binding protein of mussel byssus. Biochemistry-US 45, 14223-14231

Zhao $\mathrm{H}$, Waite $\mathrm{JH}$ (2006b) Linking adhesive and structural proteins in the attachment plaque of Mytilus californianus. J Biol Chem 281, 26150-26158

Zhou Y, Wu S, Conticello VP (2001) Genetically directed synthesis and spectroscopic analysis of a protein polymer derived from a flagelliform silk sequence. Biomacromolecules 2, 111

Zuccarello LV (1981) Ultrastructural and cytochemical study on the enzyme gland of the foot of a mollusk. Tissue Cell 13, 701 